\title{
Subductions, obduction and collision in the Lesser Caucasus (Armenia, Azerbaijan, Georgia), new insights
}

\author{
M. SOSSON ${ }^{1 *}$, Y. ROLLAND ${ }^{1}$, C. MÜLLER ${ }^{2}$, T. DANELIAN ${ }^{3}$, R. MELKONYAN ${ }^{4}$, \\ S. KEKELIA ${ }^{5}$, S. ADAMIA ${ }^{6}$, V. BABAZADEH ${ }^{7}$, T. KANGARLI ${ }^{8}$, A. AVAGYAN ${ }^{4}$, \\ G. GALOYAN ${ }^{4} \&$ J. MOSAR ${ }^{9}$ \\ ${ }^{1}$ Université de Nice Sophia Antipolis, CNRS, OCA-UMR Géosciences Azur, \\ 250 rue A. Einstein, Valbonne, France \\ ${ }^{2} 6$ bis rue Haute 92500 Rueil Malmaison, France \\ ${ }^{3}$ Université de Lille, Laboratoire Géosystèmes, FRE 3298, \\ 59655 Villeneuve d'Ascq cedex, France \\ ${ }^{4}$ Institute of Geological Sciences, Armenian Academy of Sciences, \\ 24 Baghramian ave, Yerevan, Armenia \\ ${ }^{5}$ Institute of Geology, 1 M. Alexidze Street, 0193, Tbilisi, Georgia \\ ${ }^{6}$ Institute of Geophysics, 1 M. Alexidze Street, 0193, Tbilisi, Georgia \\ ${ }^{7}$ University of Baku, Baku, Azerbaijan \\ ${ }^{8}$ Geological Institute of Azerbaijan, Geotectonics and Geodynamics, H.Javid Av., \\ 29A, Baku AZ1143 Baku Azerbaijan \\ ${ }^{9}$ University of Friburg, Earth Sciences, Friburg, Switzerland \\ *Corresponding author (e-mail: sosson@geoazur.unice.fr)
}

\begin{abstract}
In the Lesser Caucasus three main domains are distinguished from SW to NE: (1) the autochthonous South Armenian Block (SAB), a Gondwana-derived terrane; (2) the ophiolitic Sevan-Akera suture zone; and (3) the Eurasian plate. Based on our field work, new stratigraphical, petrological, geochemical and geochronological data combined with previous data we present new insights on the subduction, obduction and collision processes recorded in the Lesser Caucasus. Two subductions are clearly identified, one related to the Neotethys subduction beneath the Eurasian margin and one intra-oceanic (SSZ) responsible for the opening of a back-arc basin which corresponds to the ophiolites of the Lesser Caucasus. The obduction occurred during the Late Coniacian to Santonian and is responsible for the widespread ophiolitic nappe outcrop in front of the suture zone. Following the subduction of oceanic lithosphere remnants under Eurasia, the collision of the SAB with Eurasia started during the Paleocene, producing 1) folding of ophiolites, arc and Upper Cretaceous formations (Transcaucasus massif to Karabakh);2) thrusting toward SW; and 3 ) a foreland basin in front of the belt. Upper-Middle Eocene series unconformably cover the three domains. From Eocene to Miocene as a result of the Arabian plate collision with the SAB to the South, southward propagation of shortening featured by folding and thrusting occurred all along the belt. These deformations are sealed by a thick sequence of unconformable Miocene to Quaternary clastic and volcanic rocks of debated origin.
\end{abstract}

The Mesozoic ophiolites of the Lesser Caucasus belong to the Tethyan ophiolitic suture zone (Knipper 1975; Adamia et al. 1981; Zakariadze et al. 1983; Knipper et al. 1986) (Fig. 1). Consequently the Lesser Caucasus mountain belt recorded Mesozoic and Cenozoic geodynamic evolutions related to the closure of the Northern Neotethys ocean (Sengör \& Yilmaz 1981; Adamia et al. 1981; Dercourt et al. 1986; Ricou 1994; Nikishin et al. 1998; Yilmaz et al. 2000; Stampfi et al. 2001; Robertson 2002; Golonka 2004). In this context, the NW-SE trending Sevan-Akera suture zone extends on nearly $400 \mathrm{~km}$, north of the Sevan Lake from Amassia to the Nagorno-Karabagh region. To the SE of this region it is covered by Quaternary deposits along the Araks valley (Fig. 2). The outcrops of this arched zone reach a maximum width of $25 \mathrm{~km}$ and are characterized 


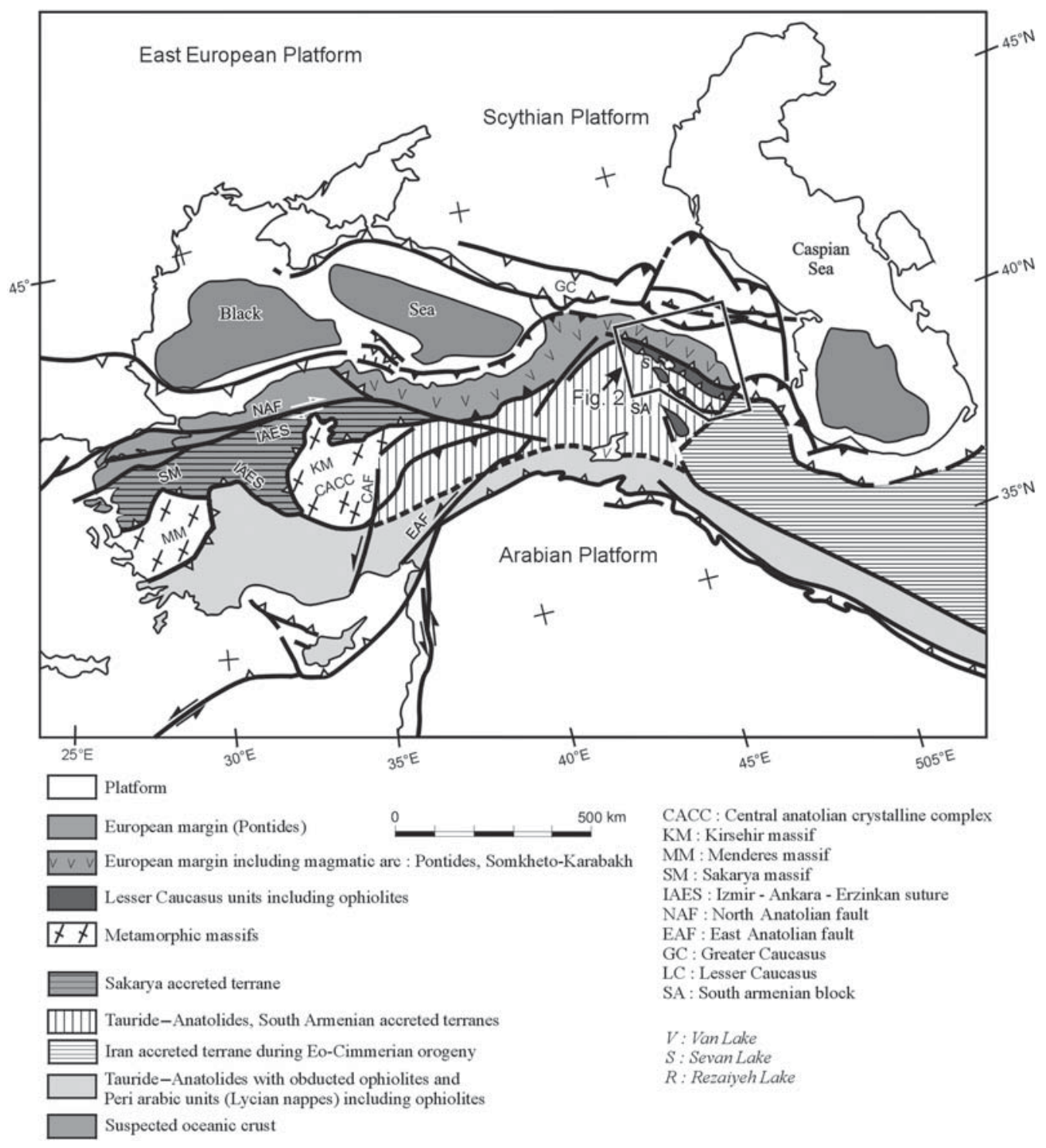

Fig. 1. Structural sketch map of the Tauride-Anatolides, Caucausus and Iranian belts. Location of Figure 2 is indicated.

by many discontinuous massifs, exposing ultrabasites, gabbros, basalts and pelagic sedimentary rocks (Knipper 1975; Gevorkyan \& Gevorkyan 2003; Aghamalyan 2004; Melikyan 2004) (Fig. 2). The location of this ophiolitic zone between Eurasia and the Daralagez continental terrane or South Armenian Block (SAB; a continental terrane of Gondwanian origin, Knipper \& Khain 1980; Monin \& Zonenshain 1987) suggests either an allochthonous unit or a real suture zone within the Lesser Caucasus belt. According to Aghamalyan (1996, 2004), the Sevan-Akera ophiolitic zone corresponds to a suture zone where Eurasian and a microplate plates have joined together. However, other outcrops of ophiolites (the Vedi and Zangezur ophiolites) are known southwestward of the SevanAkera zone (Fig. 2). Consequently the ophiolites of the Lesser Caucasus could correspond to several sutures zones (Aslanyan \& Satian 1977) or only one reflecting a complex west-Pacific type evolution of the Neotethys Ocean east of the Erzincan suture zone (Eastern Anatolia, Turkey) and west of the Iran ophiolitic ones (Knipper 1975; Adamia et al. 1981; Lordkipanidze et al. 1988; Yilmaz et al. 2000). 


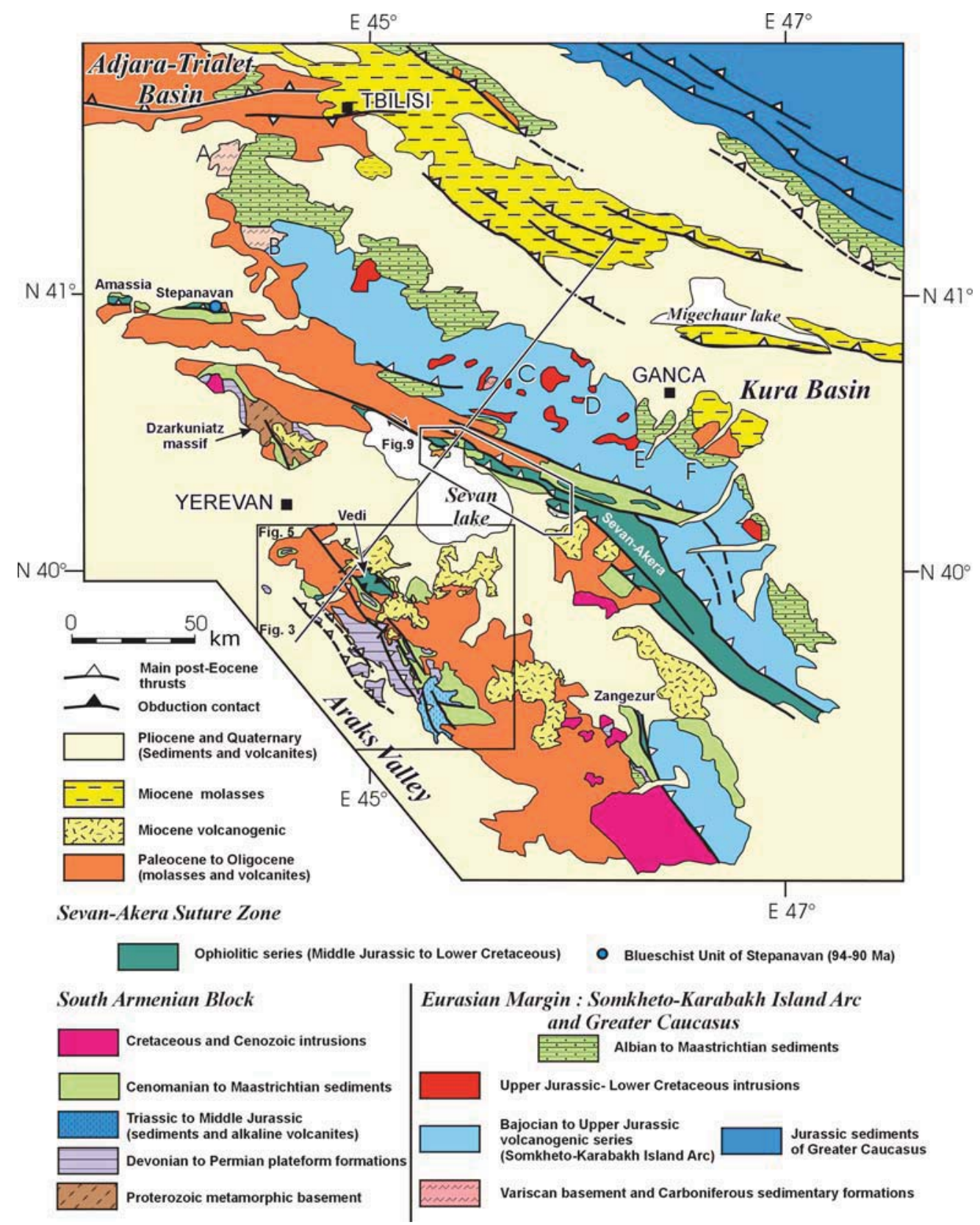

Fig. 2. Structural map of the Lesser Caucasus, modified from Nalivkin (1976) and including our observations. A, Variscan Khrami massif and its Carboniferous volcano-sedimentary cover (Georgia); B, Variscan Loki Massif (Georgia); C, Zayemchay Valley (Azerbaijan); D, Gochkarchay Valley (Azerbaijan); E, Yasamal Valley (Azerbaijan); F, Kurakchay Valley (Azerbaijan), all these locations are discussed in the text.

In the Lesser Caucasus the apparent southwestward obduction of oceanic lithosphere on the South Armenian Block (Knipper 1975; Knipper \& Khain 1980; Monin \& Zonenshain 1987) occurred during the Late Cretaceous (Sokolov 1977; Knipper \& Khain 1980). It was classically admitted that the obduction was directly related to the collision between the SAB and Eurasia. As a result 
the Eurasian plate overthrusted the ophiolites southwards (Adamia et al. 1977, 1981).

As for many examples around the world, in such structural setting, occurrences of ophiolites feature the obduction and collision stages of geodynamic evolution of mountain belts. Where the suture zone units have been preserved from metamorphism due to the collision, they may give significant information on the initial stages as the geodynamic setting of their formation and the subduction.

This belt was deformed by superimposed tectonics which makes it difficult to decipher each structure and consequently the geodynamic processes from which they resulted. Accordingly, the main debated subjects on the Lesser Caucasus are: 1) the occurrence or not of three main ophiolitic zones corresponding for some authors to three main sutures zones; 2) the modalities and timing of collision stages between the SAB and Eurasia, including the verging of continental subduction and age of its triggering; and 3) the origin of the widespread magmatic activity that occurred during Eocene time and then from the OligoceneMiocene to the Quaternary. New investigations were deemed necessary to solve these questions all related to the geodynamic evolution of the Neotethys Ocean and its closure.

According to new field surveys (mapping and acquisition of structural data) and new analytic data ( $\mathrm{Ar} / \mathrm{Ar}$ dating, geochemistry, micropalaeontological dating: Tables 1 and 2) obtained thanks to the MEBE programme support, we discuss

Table 1. Upper Cretaceous Nannofossils dating with (WGS84) GPS locations

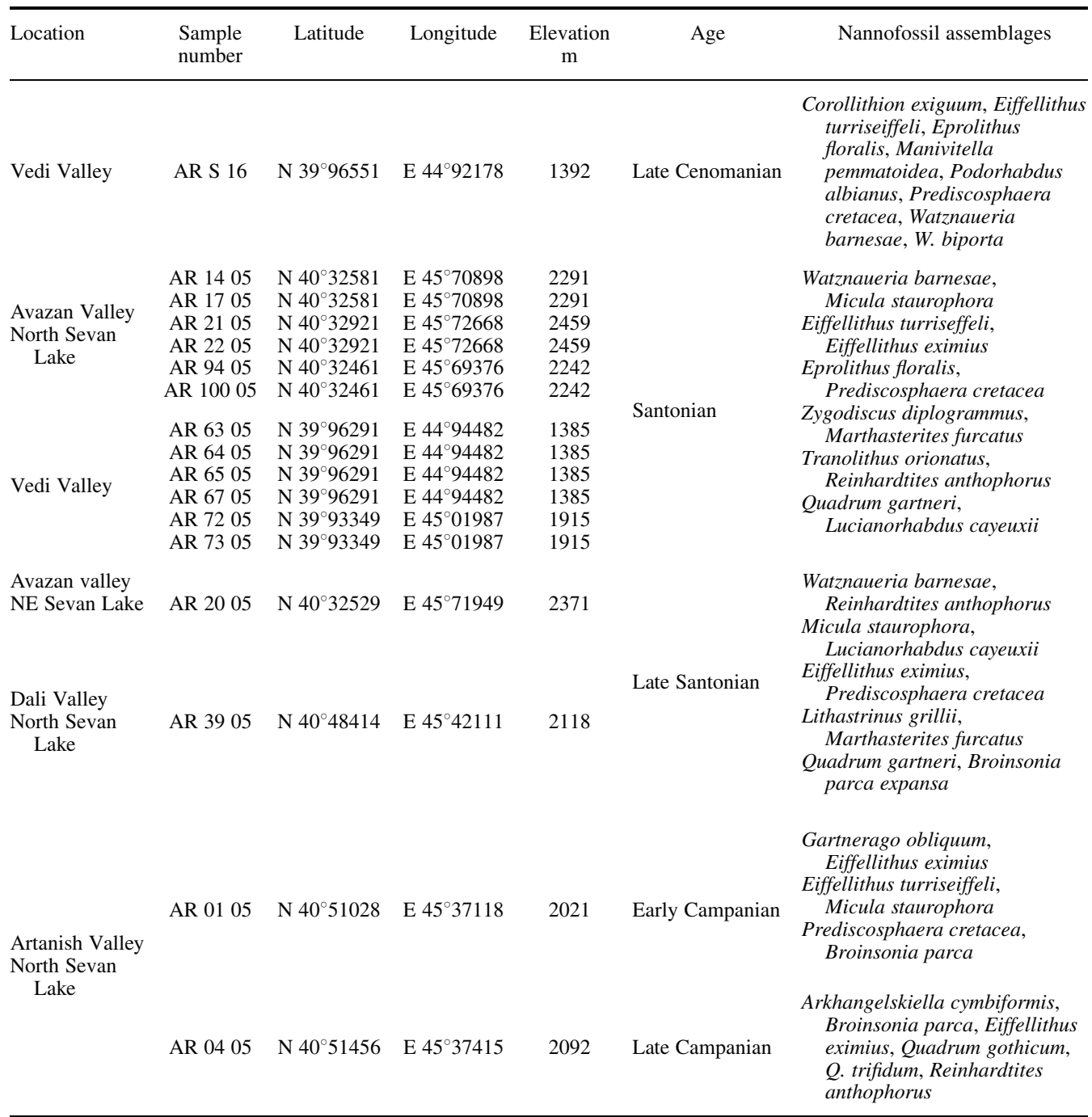


Table 2. Paleocene-Eocene Nannofossils dating with (WGS84) GPS locations

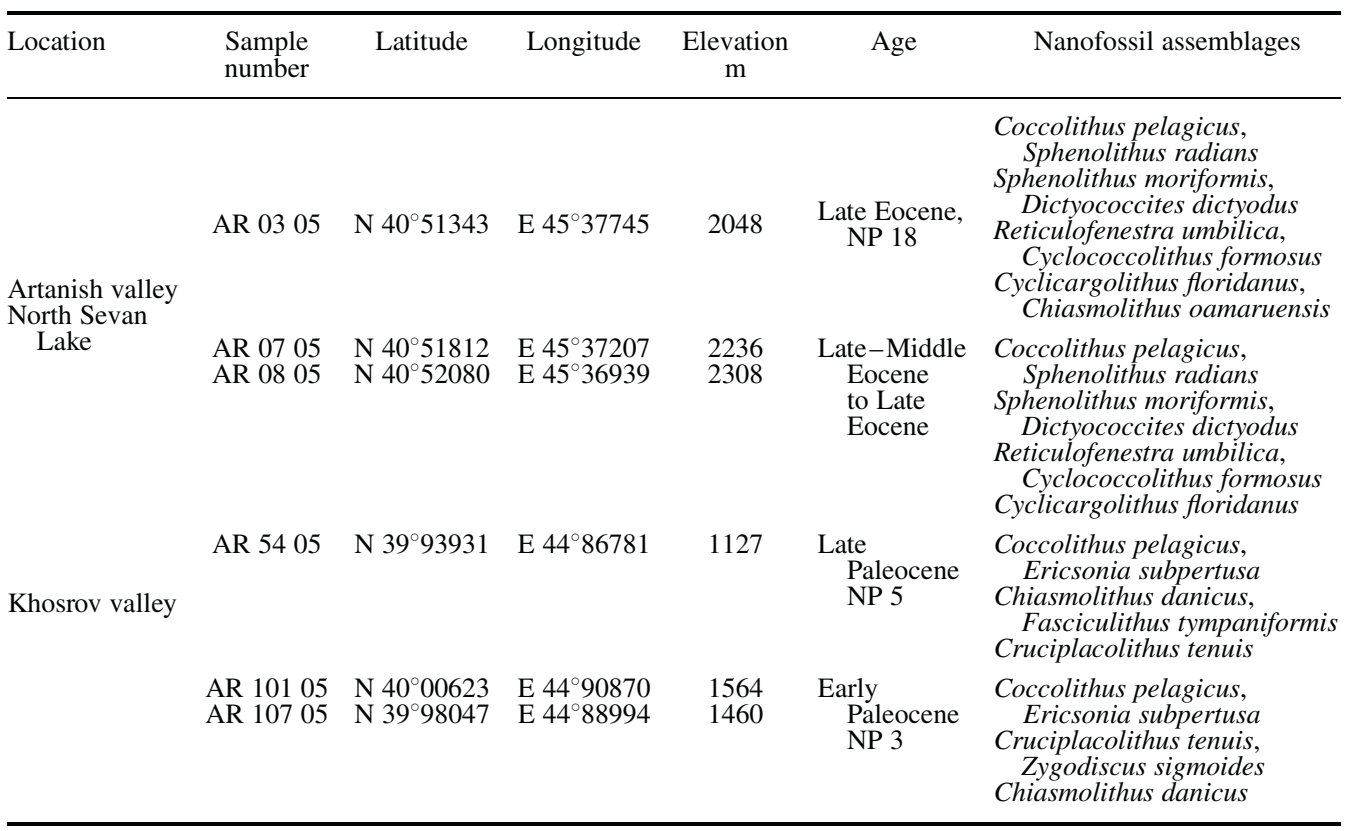

here some key points allowing us to clarify the subduction, obduction and collision processes all along the Sevan-Akera suture zone. Moreover we present a new interpretation for the structure of the Lesser Caucasus belt along a NE-SW crosssection.

\section{General structural setting}

As presented on the structural sketch map (Fig. 2) and the NE-SW trending cross-section (Fig. 3) summarizing previous data (Nalivkin 1976) and our observations, three main lithostructural domains can be distinguished in the Lesser Caucasus, from NE to SW: 1) Eurasia; 2) the Sevan-Akera suture zone; and 3) the South Armenian Block (SAB). This structural framework was previously proposed by Milanovski (1968). The main difference between the Milanovski's section and ours is the occurrence of ophiolitic nappes (the Vedi ophiolites) in front of the Sevan-Akera ophiolitic zone (Fig. 3). Satian et al. $(1979,2005)$ consider the Vedi ophiolites as remnants of a small palaeo-ocean. Knipper \& Sokolov (1976) and Sokolov (1977) provided evidence for an allochthon position of the ophiolitic unit on the base of structural data. Others differences concern the occurrence of post-Eocene reverse and thrust faults which accommodated shortening in the basement of the SAB and the Sevan-Akera ophiolitic zone (Figs $2 \& 3$ ).

\section{Evidence for subduction processes}

Subduction along the Eurasian margin. As documented by previous studies performed on the Lesser Caucasus the subduction of the Tethys is evidenced by a thick and mainly calcalkaline volcanogenic and volcanoclastic series dated as Bajocian to Santonian (e.g. Adamia et al. 1981 for a review). At this period of time the northern Lesser Caucasus was characterized by an island arc domain called the Somkheto-Karabakh Island Arc (Knipper 1975; Adamia et al. 1977, 1987; Ricou et al. 1986).

The basement formations are quite similar to those known all along the Eurasian margin. Indeed they are exposed in three Variscan metamorphic massifs in Georgia (Transcaucasian massif): the Khrami (A on Fig. 2), Loki (B on Fig. 2) and Dzirula salients (Kazakhashvili 1950; Adamia 1968; Kekelia \& Khutsishvili 1980; Adamia et al. 1983, 1987; Adamia 1984; Shengelia et al. 1989; Abezadze et al. 2002). In the Khrami massif the Carboniferous volcanoclastic series unconformably overlie the Variscan metamorphic basement (Adamia 1968, 1984; Adamia et al. 1983). This volcanogenic-sedimentary formation is transgressively overlain by the Liassic, Upper JurassicLower Cretaceous and Cenomanian sediments and volcanogenic series. Upper Palaeozoic metamorphic rocks are also described in the Azerbaijan part of the Northeast Lesser Caucasus flank (Nalivkin 


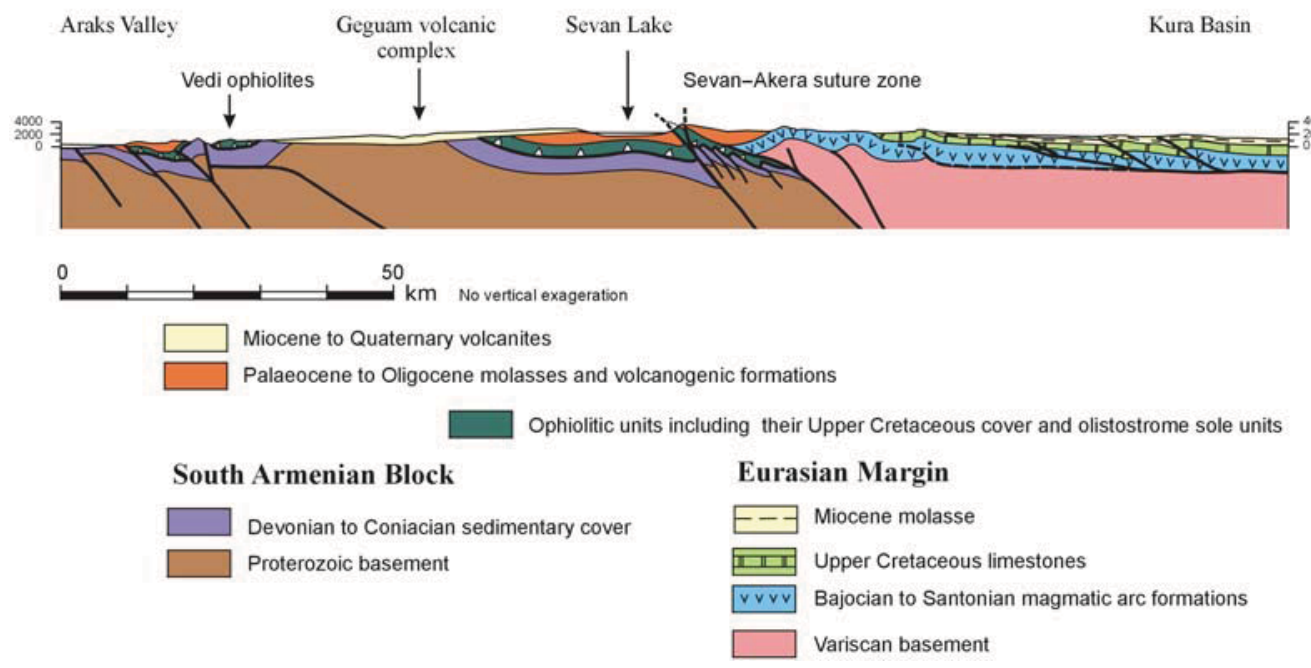

Fig. 3. Cross-section of the Lesser Caucasus. Location is shown on Figure 2.

1976) (see mark C on Fig. 2). We studied the Mesozoic volcanogenic series in four valleys near Ganca (Azerbaijan) (Fig. 2) from west to east: Zayemchay (C on Fig. 2), Gochkarchay (D on Fig. 2), Yasamal (E on Fig. 2), Kurakchay (F on Fig. 2). These observations allow us to present a synthetic stratigraphic $\log$ of the Eurasian margin of the northeastern part of Lesser Caucasus (Fig. 4). Bajocian-Bathonian formations $( \pm 2400 \mathrm{~m})$ present a basal conglomerate on the Variscan basement (see mark A on Fig. 2) and upwards volcanoclastic series, sandstones, marl with Ammonites and Cancellophycus, basalts, volcanoclastic turbidites and andesite on top. This series indicates a major magmatic activity during the Middle Jurassic (Maghakyan et al. 1985; Lordkipanidze et al. 1988). The Oxfordian stage is composed of a transgressive sequence with conglomerate, siltstones, mudstones and reef limestones (Fig. 4). The Kimmeridgian features massive intrusions (granodiorites, gabbros, quartz-diorites, plagiogranites) (Melkonian 1976; Lordkipanidze et al. 1988). The gabbroic Dachkasan intrusion is responsible for the metamorphism of limestones into white marbles (Fig. 4). The intrusions caused many ore-deposits: 1) Middle and Upper Jurassic epigenetic copper and barite-polymetallic deposits; 2) Middle Jurassic gold-bearing porphyry copper deposits; 3) Upper Jurassic iron skarn deposits; and 4) Lower Cretaceous porphyry copper deposits (Kekelia et al. 2004; Melkonian \& Akopyan 2006; Babazadeh et al. 2007). Coniacian formations unconformably overlie (unconformity U2, mark E on Fig. 2) the Upper Jurassic intrusions and Lower Cretaceous sedimentary rocks that are very much reduced in thickness in that part of the belt (Fig. 4). The Coniacian stage consists from bottom to top of a red conglomerate, sandstones and reef limestones indicating a shallow water environment at that time. A similar palaeoenvironment is also featured by the Santonian formations. They are characterized by a transgressive sequence (conglomerate, sandstones and limestones) including prismatic basalt flows. In some places, the series contains on its top pillowed and massive basalt lava flows. Consequently the magmatic arc was still active during this period of time along this part of the Eurasian margin. The end of magmatic activity occurred in the Campanian to Maastrichtian stages. The formations are made of thin layered pelagic limestones with some carbonates turbidites.

The compiled lithostratigraphic log (Fig. 4) characterizes an arc-type evolution of the active Eurasian margin from Bajocian to Late Jurassic all along the Lesser Caucasus northern flank. In this part of the Eurasian margin some ages of volcanogenic series (Late Cretaceous) are younger than in the northwestern part (Transcaucasian massif, Georgia). The southeastward younging of magmatic ages may result from migration of the magmatic arc during the Late Cretaceous.

On this basis we suggest that an oceanic plate subducted northward (if we exclude any major rotation since this time) beneath the Eurasian plate. At least it is well evidenced from Bajocian to Santonian $(100 \mathrm{Ma})$, with younger ages present to the SE. This oceanic plate can be correlated to the northern Neotethys part or to one marginal basin related to an intra-oceanic subduction. In 


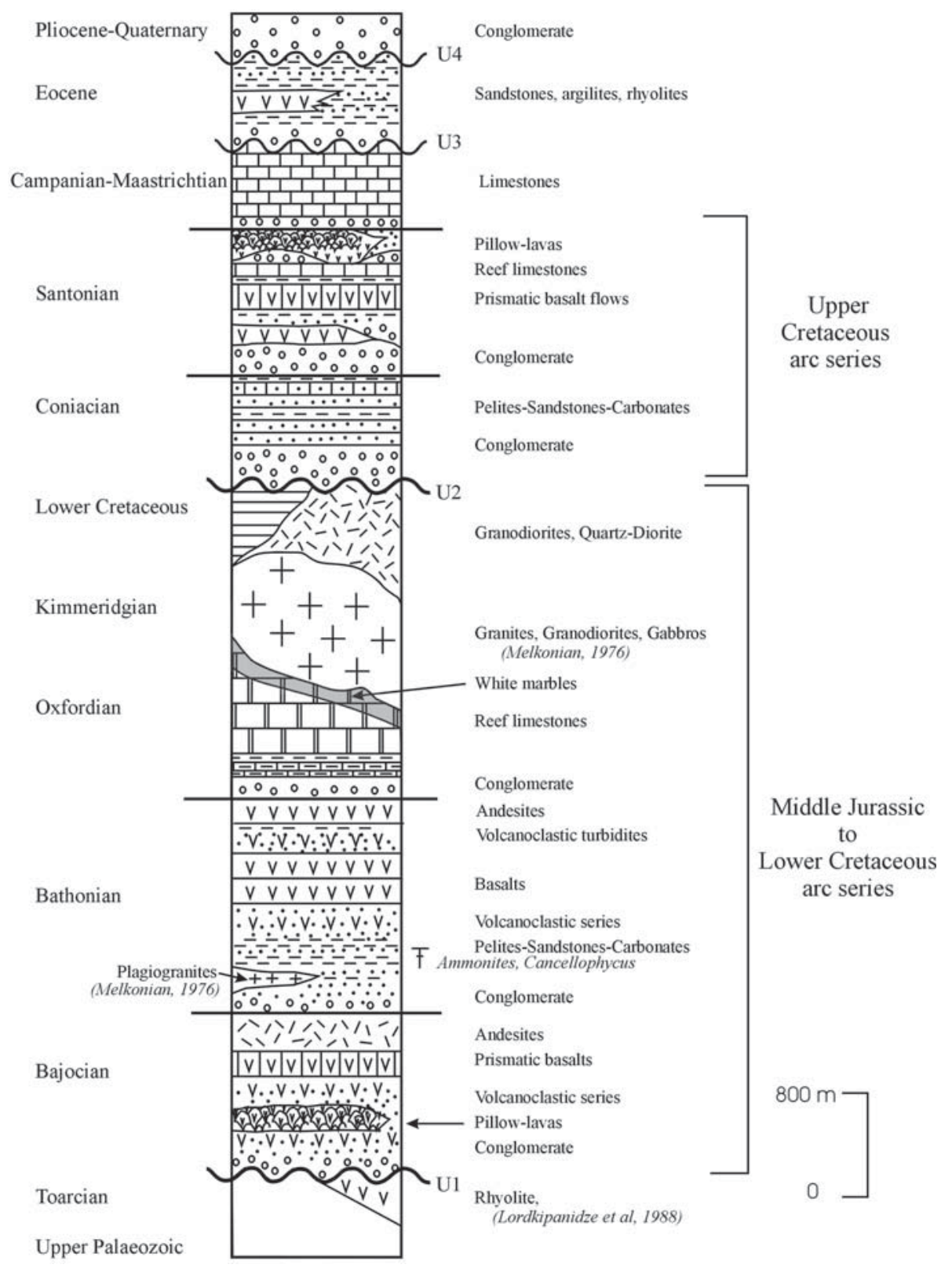

Fig. 4. Synthetic lithostratigraphic log of the Eurasian margin in the Lesser Caucasus (Armenia and Azerbaijan).

order to test these hypotheses we present below new evidences for an intra-oceanic subduction in the Neotethys domain during these times.

\section{Evidence for an intra-oceanic subduction}

According to petrological and geochemical data from volcanites, Lordkipanidze et al. (1988) suggested a Middle Jurassic Marianas-type subduction in the Lesser Caucasus region. New evidence for an intra-oceanic subduction is described in detail in a companion paper (Rolland et al. 2010), consequently we point out and summarize here the main results.

The northwestern part of the Sevan-Akera suture zone (SW of the Stepanavan town, Fig. 2) 
is characterized by tectonic units outcropping within a nappe anticline in which the core is made of blueschist slices (Aghamalyan 1981, 2004; Galoyan et al. 2007; Galoyan 2008; Rolland et al. 2007). The blueschist units protoliths correspond to unroofed sediments along a subduction zone. The HP-LT metamorphism was dated 90-80 Ma by $\mathrm{K}-\mathrm{Ar}$ methods (Aghamalyan 1998). Further, it was found to be a two-stage evolution using $\mathrm{Ar} / \mathrm{Ar}$ dating technique (on phengites), with HP-LT stage at 94-90 Ma followed by a retrograde Green Schist/epidote amphibolite metamorphism during exhumation in the Late Cretaceous (71-74 Ma, $\mathrm{Ar} / \mathrm{Ar}$ on phengites, Rolland et al. 2007, 2010). The blueschist unit is overthrusted by unmetamorphosed ophiolites, Late Jurassic in age (Danelian et al. 2007). In that area and in the other ophiolitic zones of the Lesser Caucasus (Sevan-Akera, Vedi), this geodynamical setting is also well documented by the magmatic evolution of the ophiolites. Petrologically and geochemically (major, trace, REE and isotopic geochemistry) these ophiolites are characterized by a slight island arc signature (Rolland et al. 2009). Such geochemical features are typical of oceanic crust formed in a back-arc setting (Galoyan 2008; Galoyan et al. 2009). Above the ophiolites, an Upper Cretaceous calc-alkaline volcanic series is evidenced, lying on a sedimentary unconformity marked by Albian conglomerates and limestones (Aghamalyan 1998; Galoyan et al. 2007). The geochemical data, including isotopic $\mathrm{Sr}-\mathrm{Nd}$ compositions, obtained on these lavas indicate a volcanic arc-type series on top of the ophiolites (Galoyan et al. 2007, 2009; Galoyan 2008; Rolland et al. 2009). Moreover, the structural position of the Stepanavan blueschists unit in the core of a nappe anticline overthrusted by ophiolites and arc series suggests an intra-oceanic subduction context in the stage preceding collision of the SAB with the Eurasian margin.

According to these structural, petrological and geochemical results one can suggest that this part of the Neotethys Ocean was, at least from Middle Jurassic to Campanian in age, featured by an intraoceanic subduction to its south and a subduction below the Eurasian continental plate to the north. These new results are significant constrains to the geodynamic processes evolution of the Lesser Caucasus at these periods of time.

\section{Obduction modalities}

As previously described by other works, several ophiolitic series are found in North and Central Armenia (Fig. 2). They have slightly different structures as a result of their lithologic and structural settings, but are thought to be remnants of a single obducted sequence (see Rolland et al. 2010). The ophiolitic series of the North Sevan Lake, Amassia and Stepanavan (Fig. 2) (Sevan-Akera ophiolites) (Knipper 1975; Adamia et al. 1977; Adamia et al. 1980; Maghakyan et al. 1985; Adamia et al. 1987) are found along the main suture joining the SAB and the Eurasian margin, while the Vedi ophiolites are an allochthonous nappe thrusted over the SAB (Knipper \& Sokolov 1977; Sokolov 1977; Adamia et al. 1981). The Zangezur ophiolites located between the Sevan-Akera suture zone and the Vedi ophiolites correspond to some slivers of ophiolites unroofed along thrust faults during collision (Fig. 2) (Aslanyan \& Satian 1977, 1982; Knipper \& Khain 1980).

One of the main characteristics of these ophiolitic rocks is the very low grade and even, in most cases, the absence of any metamorphism related to subduction/collision stages. The main parts of the ophiolitic units are very well preserved excepted in some shear zones, especially at the base of the obducted sequence, in which some low greenschist facies metamorphic crystallisations occur. The ophiolites record a low metamorphic grade imprint related to heterogeneous hydrothermal alteration dating from oceanic stages (Rolland et al. 2010). Even in the Stepananvan area, the main ophiolitic body is unmetamorphosed. There, its rests on a tectonic mélange mainly composed of palaeo-accretionary prism blueschist facies rocks (Rolland et al. 2007).

The obduction event is well documented in the Vedi area (Southeast of Yerevan, Armenia) (Figs $2 \& 5$ ), where the frontal obduction contact is exposed (Figs $6 \& 7$ ). In that part of the Lesser Caucasus, ophiolitic rocks are thrusted over platform series of the SAB (Sokolov 1977). In order to describe the obduction modalities it is important to identify at first the nature of the autochthon. Is this autochthon a part of the Eurasian margin or does it correspond to an exotic terrane originating from a southerly position in the Neotethys domain?

\section{The SAB autochthon}

In the Lesser Caucasus, the SAB (also called Daralagez continental terrane) is mainly exposed in Armenia and corresponds of a Proterozoic metamorphic basement, an incomplete Palaeozoic sedimentary succession, Triassic and some Jurassic formations in Nakhijevan province (Azerbaijan), Upper Cretaceous sedimentary series, Paleocene to Oligocene detrital and volcanogenic rocks, Miocene volcanogenic rocks and Plio-Quaternary volcanites (Nalivkin 1976) (Figs $3 \&$ 5).

The Proterozoic basement is made of metamorphic rocks characterized by gneisses, micaschists 


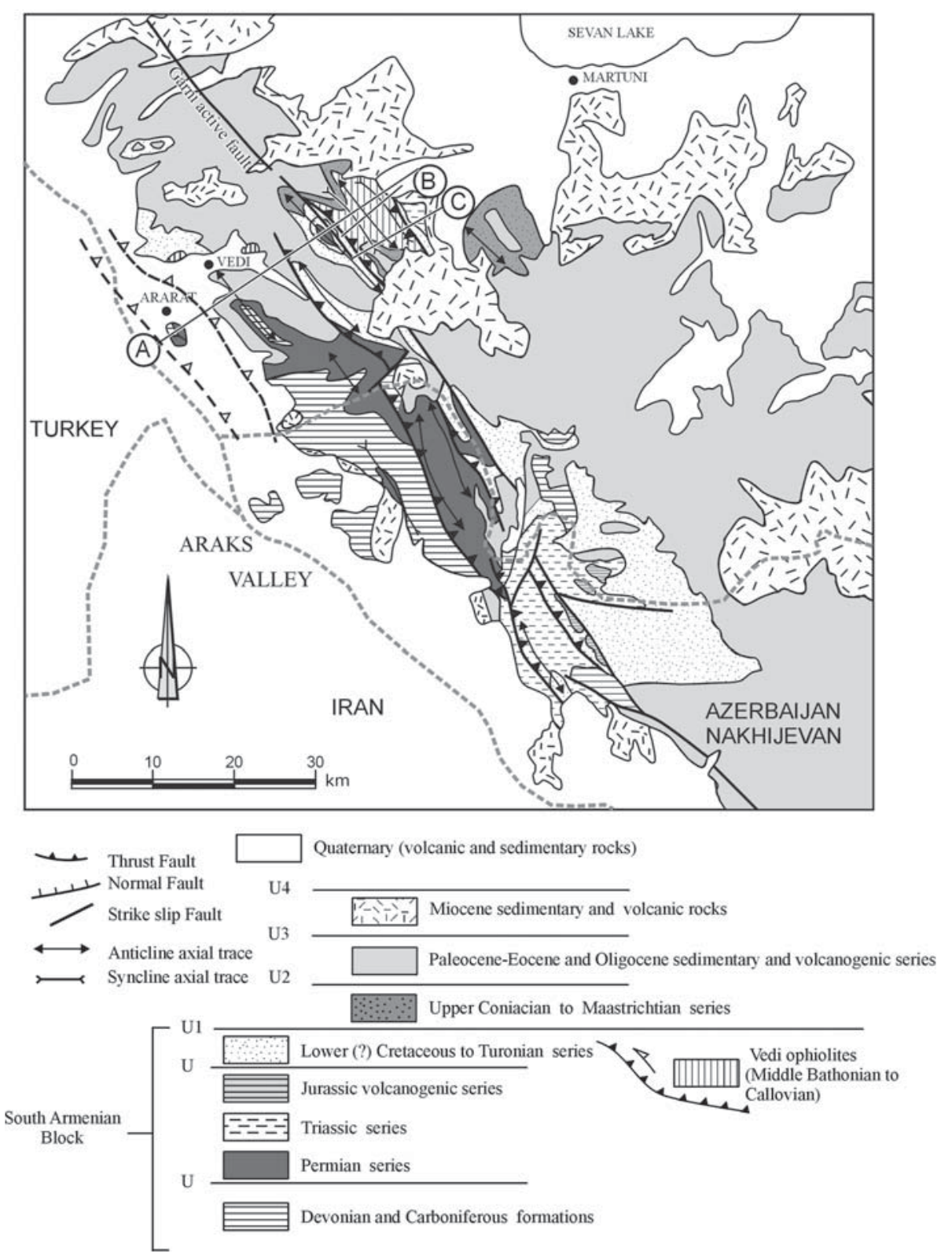

Fig. 5. Structural map of the Vedi area (Armenia).

and leucogranite intrusions. It is well exposed NE of Yerevan, in the Dzarkuniatz massif (Aghamalyan 1998) (Fig. 2). The Palaeozoic rocks of the SAB in Armenia are mainly localized in the southwestern part of the country (Figs $2 \& 5$ ). From bottom to top, the following succession of sedimentary rocks has been distinguished (Paffenholtz 1959; Karyakin 1989).
(1) Upper Devonian series (Frasnian-Famennian) composed of at least $1000 \mathrm{~m}$ thick detrital rocks including quartzites, sandstones and argillites.

(2) $500-700 \mathrm{~m}$ thick Carboniferous reef limestones.

(3) A Permian platform type section composed of 500-1500 m thick black limestones and 


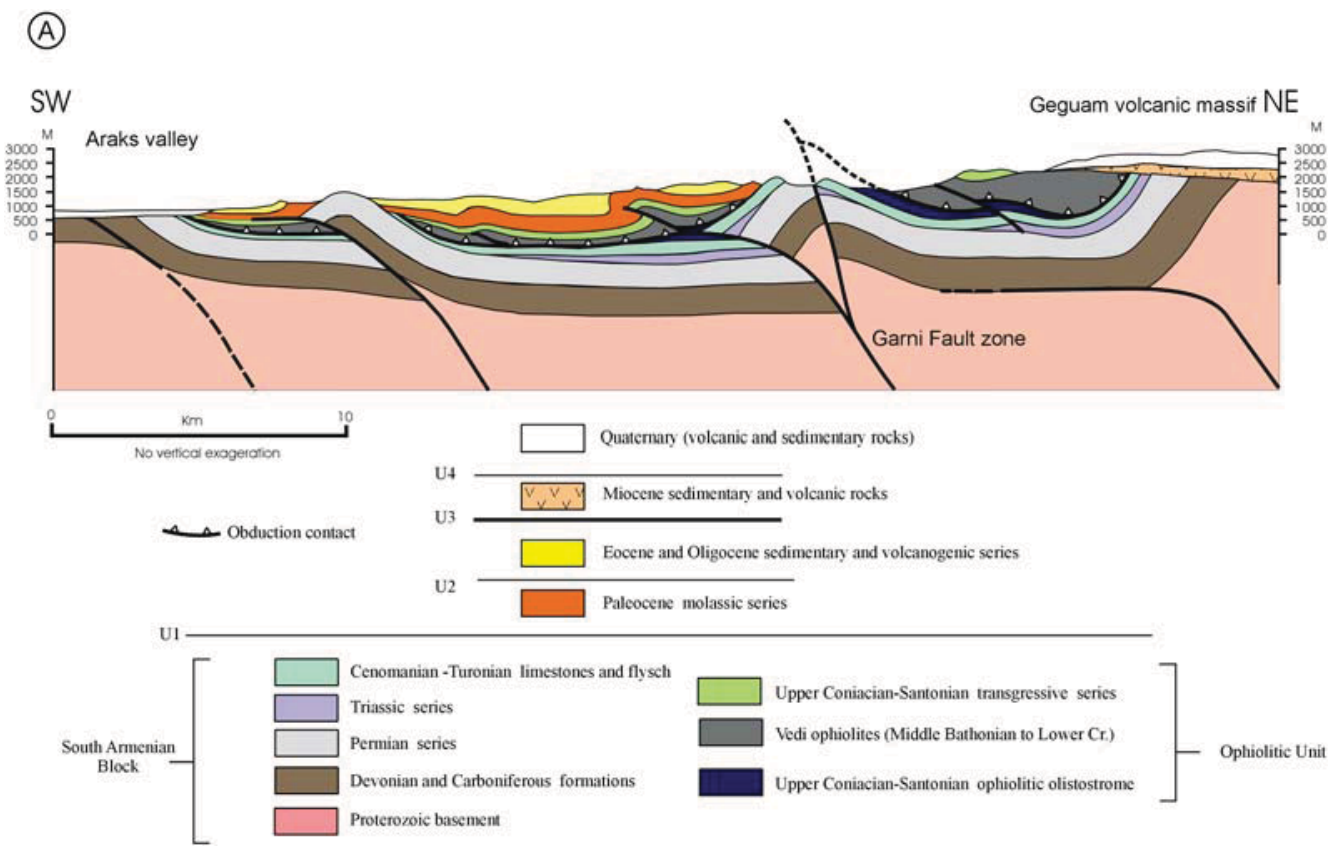

Fig. 6. Geological cross-section of the Vedi area (Armenia).

\section{(a)}

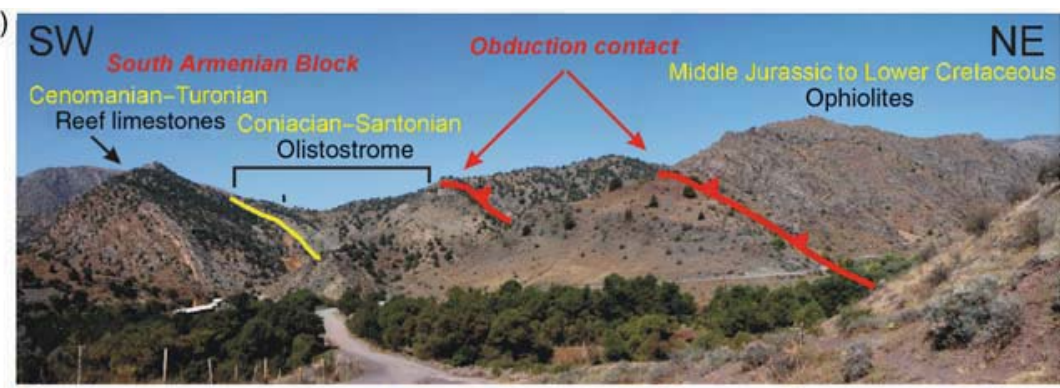

(b) NW

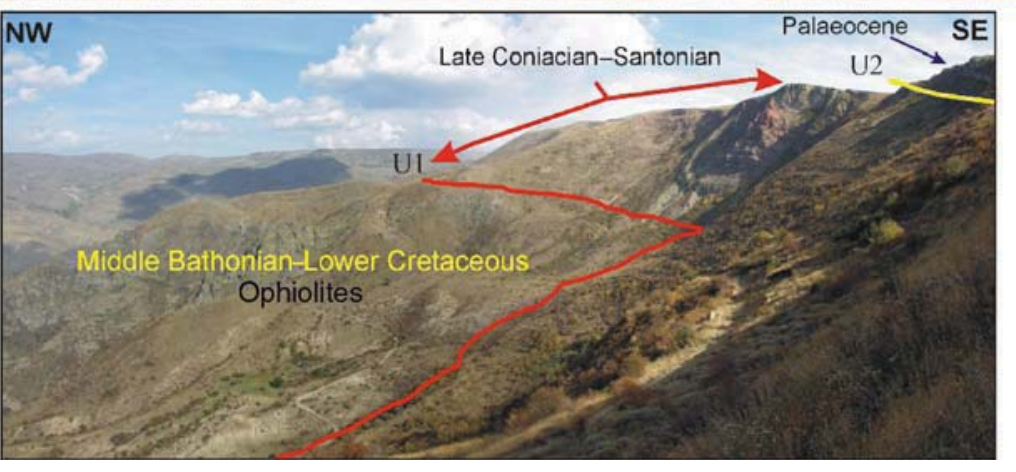

Fig. 7. Photographs of the obduction contact in Vedi area (a) and on the formations overlying the ophiolites (b). Unconformities $\mathrm{U} 1$ is related to the obduction event and $\mathrm{U} 2$ is related to the first collision stage. 
marls with occurrences of bitumen. As the Upper Devonian formations they could represent a source rock for hydrocarbon. They disconformably overlie the Devonian and Carboniferous formations. Some syn-sedimentary normal faults occur in the sequence.

The contact of the sedimentary cover with the basement is unknown in these areas (Figs 5 \& 6) The metasedimentary rocks exposed in the Dzarkuniatz massif could belong to the Proterozoic or to the Upper Devonian-Permian formations. Normal faults are suspected in the Devonian-Carboniferous formations as deduced by the geometry of the bedding within the Cenozoic structures (fold), (Fig. 5 and cross-section Fig. 6).

Lower Triassic rocks are conformably overlying on the Upper Permian limestones (Fig. 5). The series are composed of thin layered conodont rich limestones (Grigorian 1990), which evolve upward to detrital series composed of sandstones, black siltstones and mudstones of Late Triassic age. The thickness of the Triassic formations ranges from 700 to $900 \mathrm{~m}$.

In Armenia, rocks from the Jurassic period are unknown in the southern part of the SAB. However, tens of kilometres southeastward in Nakhijevan (Azerbaijan) and in Iran (south to Araks valley) (Fig. 5), $500 \mathrm{~m}$ thick Lower and Middle Jurassic are described on top of the Upper Triassic section (Lordkipanidze et al. 1988). Palaeomagnetic data from Middle Jurassic alkaline basalts and from Aalenian to Bajocian sediments indicate a palaeo-latitude of $21.5^{\circ} \mathrm{N} \pm 3.7^{\circ}$ during this period of time (Bazhenov et al. 1996). The sedimentary sequence is characteristic of a platform containing Ammonites, Briachiopodes and Pelecypodes (Bazhenov et al. 1996).

Cenomanian and Turonian carbonates unconformably overlie the previous formations (Fig. 6). They are composed of thick reef limestones with some thin marl intercalations (Eghoyan 1955; Paffenholtz 1959; Sokolov 1977; Hakobyan 1978). In Vedi Area, the reef limestones are overlain upward by a Upper Cenomanian flysch (new dating by nannofossils, sample AR S 16, Table 1) thicker southward than northward (Sokolov 1977) and by a Upper Coniacian-Santonian olistostrome (Fig. 8) (Eghoyan 1955; Rengarten 1959; Hakobyan 1976, and ages we obtained from nannofossils, samples AR 63 05, AR 64 05, AR 6505 and AR 67 05, Table 1) made of ophiolitic blocks contained in a muddy matrix (Fig. 4).

According to the stratigraphic and lithological data of the $\mathrm{SAB}$, in comparison with the Eurasian characteristics (Fig. 4) the SAB clearly differs from the Eurasian margin. This is also evidenced by tectonic phases recorded in the $\mathrm{SAB}$ and the Eurasian margin basement.
The SAB metamorphic basement is Proterozoic (Aghamalyan 1969, 1978, 1998; Belov \& Sokolov 1973), the Eurasian margin is mainly Variscan (Adamia et al. 1983; Adamia 1984, Zakariadze et al. 1998). The Palaeozoic series of the SAB mainly consist of platform-type carbonates whereas the sedimentary successions overlying the Eurasian crystalline basement are metamorphic schists dating back to the Visean and older. Moreover we do not find any sign of rifting all along the Eurasian margin series which could explain a drift to the south of the SAB after the Variscan orogeny. The palaeomagnetic data indicate a southerly palaeo-latitude of the SAB during the Early and Middle Jurassic (Barzhenov et al. 1996). All these data argue for a Gondwanian origin of the SAB located during Middle Jurassic, $2000 \mathrm{~km}$ south of its present location (Barzhenov et al. 1996).

\section{Ophiolitic unit}

This ophiolitic sequence outcrops within a folded klippe (Figs 2, $5 \& 8$ ). According to the palaeontological data (Radiolarians), the Vedi ophiolites are mainly Middle Jurassic (Middle to Late Bajocian) (Danelian et al. 2008, 2010) and Late Jurassic (Danelian et al. 2010) and probably Early Cretaceous in age (Belov et al. 1991). The geochemistry undertaken on the oceanic crust indicates an N-MORB origin (Galoyan et al. 2007, 2009; Galoyan 2008; Rolland et al. 2009, 2010) and some basalts located on top of the previous ones are signs of an alkaline component (Tsameryan et al. 1988; Galoyan 2008). The geochemical compositions and the fact that peridotites, gabbros and plagiogranites were on the ocean-floor together (the radiolarites cover all these rocks) (Galoyan et al. 2008) indicate a slow-spreading oceanic crust, put in place in a back-arc domain, and overlain by a hot-spot series (see Rolland et al. 2010 for a synthesis).

According to previous works, the whole ophiolitic sequence was interpreted as an ophiolitic melange (Sokolov 1977; Zakariadze et al. 1983). In contrast, we distinguish ophiolitic units comprising of preserved slices of oceanic crust thrusted over the Upper Coniacian-Santonian olistostrome of the SAB reworking the ophiolites (Figs $6 \& 8$ ).

On top of the ophiolites, we observed reef-type sediments, OIB lavas and arc-type volcanic rocks (andesites lava flows), which unconformably cover the pillow-lavas (Fig. 8). These intra-oceanic arctype volcanic series have been evidenced from geochemical data (Galoyan et al. 2007, 2009; Galoyan 2008).

An Upper Coniacian to Santonian transgressive series disconformably overlies the ophiolitic Vedi unit. This transgressive series is characterized 
(B) $\mathrm{sw}$

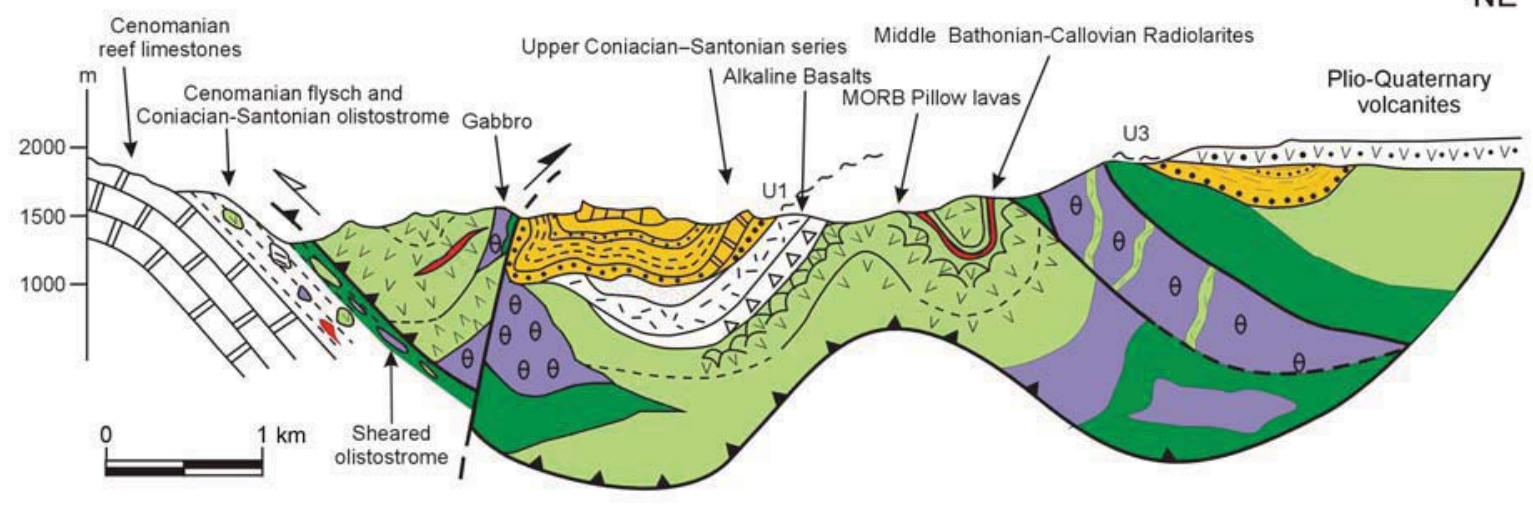

(C)

WSW

ENE

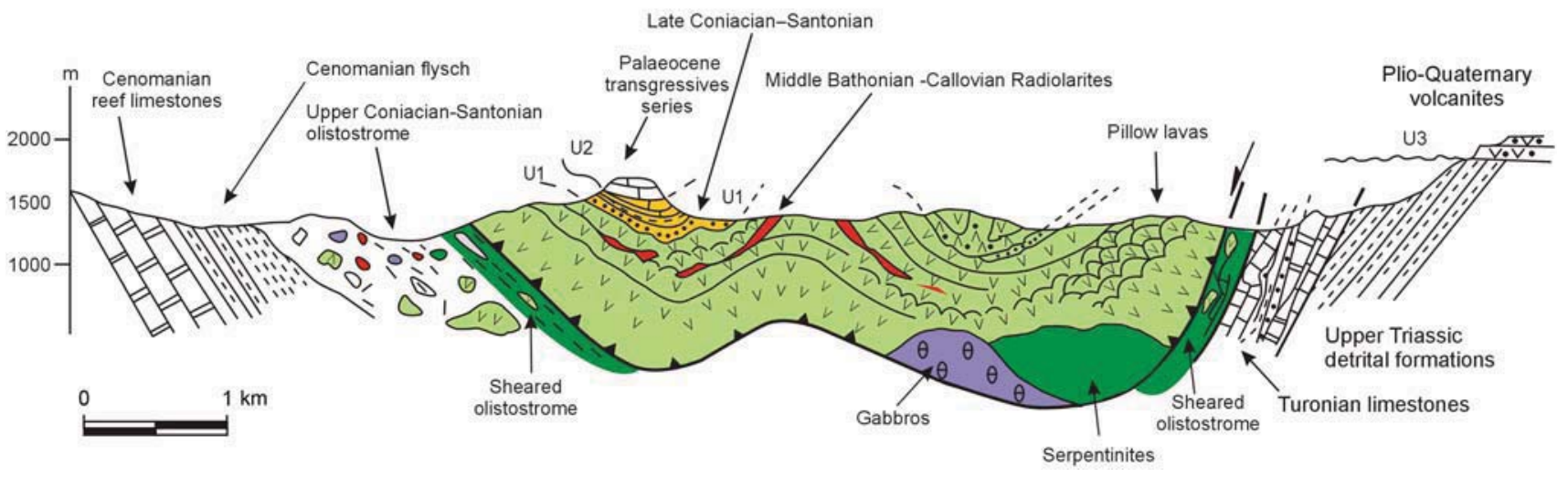

Fig. 8. Geological cross-sections of the Vedi ophiolites, locations are shown on Figure 5. 
upwards by breccias and conglomerates, which rework ophiolitic rocks and the CenomanianTuronian autochthonous limestones (Fig. 7). The conglomeratic formation grades laterally into reef limestones composed of Upper Coniacian Hippurites fossils. Green mudstones, siltstones and thin turbiditic layered reef limestones with some pink levels overlie the reef limestones (Fig. 7). Late Coniacian-Santonian ages of the green mudstones were obtained by nannofossils (samples AR 72 05, AR 73 05, Table 1).

One can note that in the Vedi area the Campanian and Maastrichtian are rare or missing. This indicates erosion or non-deposition due to the obduction uplift starting during the Late Coniacian and ongoing during Campanian to Maastrichtian times.

Moreover, the HP metamorphism of the Stepanavan Blueschist unit is dated at $94-90 \mathrm{Ma}$ and its exhumation at $74-71 \mathrm{Ma}$ (Rolland et al. 2007). This exhumation is ascribed to the underthrusting of the SAB continental lithosphere still attached to the subducted slab below the oceanic crust section during the first stage of the obduction process. In this case, unroofing the Blueschist unit within the subduction channel could be the result of driven forces conducted by the low density of the continental crust.

In summary the back-arc basin is thrusted over the SAB during Late Coniacian-Early Santonian time, as evidenced by 1) the ophiolitic olistostrome age; and 2) the occurrence at the same time of reef limestones on top of the ophiolites which suggest a shallow marine environment indicating uplift of the oceanic crust along the obduction thrust. This obduction stage was still active during Campanian and Maastrichtian explaining the absence or the pauce of sedimentation in the Vedi area south of Lesser Caucasus.

\section{Collision}

The collision stages in the Lesser Caucasus are not well known. This is mainly due to superimposed tectonics which occurred in this region from Late Cretaceous to present. The first aim of our studies was to clearly identify the timing of collision triggering or more exactly that of the continental subduction of the SAB. Major unconformities and structures were dated allowing the reconstruction of the tectonic evolution of this collision event.

\section{Beginning of the collision between $S A B$ and Eurasia}

Along the Sevan-Akera suture zone North of Sevan Lake, late-Middle to Upper Eocene nummulitic series unconformably overlie the ophiolite units, the Eurasian margin and the SAB (Unconformity U2) (Figs 2, $9 \& 10$ ). According to these stratigraphic

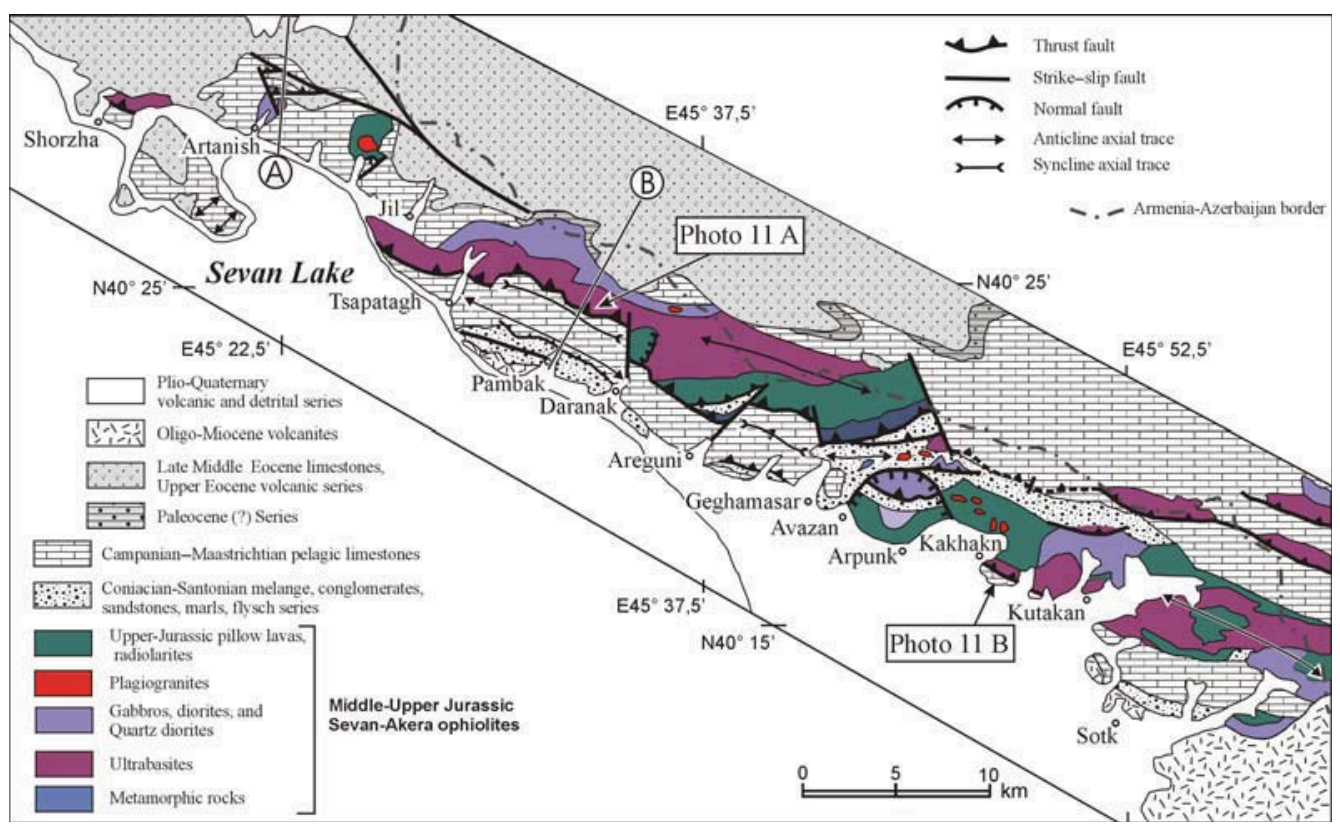

Fig. 9. Structural sketch map of the northern Sevan Lake area (Sevan-Akera suture zone), (Armenia and Azerbaijan). Modified from Nalivkin (1976), and including our observations. 

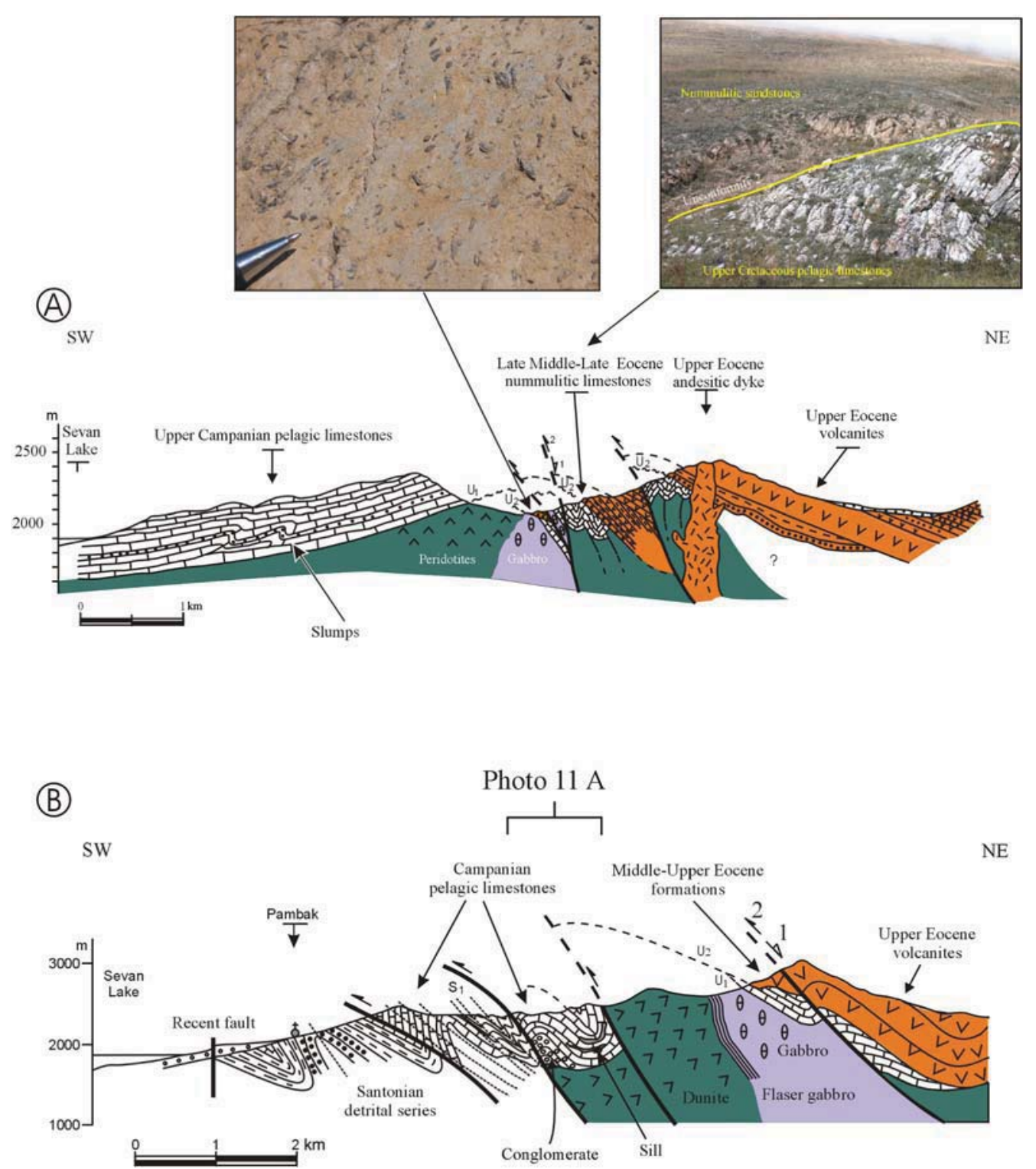

Fig. 10. Geological cross-section of the northern Sevan lake area (Armenia and Azerbaijan). Photographs represent the Nummulites of the Nummulitic sandstone of late-Middle Eocene age and the unconformity U2 of the late-Middle Eocene on the Campanian pelagic limestones.

data the onset of the collision between the SAB and Eurasia occurred before the late-Middle Eocene. In detail the unconformable sedimentary deposits are characterized upward by conglomerates reworking Upper Cretaceous pelagic limestones, ophiolites and Lower Eocene andesites. Sandstones and nummulitic limestones overlie the conglomerate. The sedimentary succession of few tens of metres thickness is interbeded with andesitic lava flows.
Upwards, the series is characterized by thick volcanic layers made of andesitic and trachytic lavas (Fig. 10). The late-Middle to Late Eocene age (NP 18) of the base of this formation was obtained by nannofossiles (samples AR-03-05, AR-07-05 and AR-08-05, Table 2). In the western part of North Sevan area this volcano-sedimentary series unconformably overlies thick (maximum $2000 \mathrm{~m}$ thick) Lower to Middle Eocene calcalkaline volcanogenic 
series mainly made of andesite, trachyte, rhyolites and sandstones (Lordkipanidze et al. 1988).

This is still well expressed on the Eurasian margin in Armenia and Azerbaijan where the lateMiddle Eocene formations unconformably cover the Middle Jurassic to Upper Cretaceous formations (Fig. 2). Consequently the late-Middle Eocene deposition occurred after a period of erosion. The sedimentary products of this erosion event have to be found southwestward.

\section{Syn-collisional basin}

The Paleocene is not well expressed in the area of the Sevan-Akera suture zone. Danian sandstones have been described (Abovyan 1961; Sokoloy 1977) but they are not clearly exposed all along the suture zone. In this part of the belt the Paleocene time is characterized by uplift, erosion and folding. Cross-sections and maps from the suture zone in North Sevan area (Figs 3, 9 \& 10) illustrate well Paleocene folds unconformably covered by the lateMiddle Eocene nummulitic sandstones and limestones. There, the Campanian pelagic limestones that overlie the ophiolites unit are folded (Fig. 10).

Nevertheless to the south in the Vedi area the Paleocene detrital series disconformably overlie the obducted ophiolites and the SAB. These formations are well developed and characterized by thick molassic deposits (more than $1000 \mathrm{~m}$ in thickness) (Figs 5 \& 6). The detrital sequences are made, from bottom to top, of conglomerates, sandstones, greywackes, siltstones, marls and some algae limestones interlayers. The detrital series mainly reworked the ophiolites and the SAB autochthon The Paleocene age of this formation was obtained by nannofossils (samples AR-54-05, AR-101-05, AR-107-05, Table 2) and are in agreement with the previous dating (Nalivkin 1976). The Paleocene basin to the south has to be considered as a foreland basin in front of a collisional belt located to the north (Figs 2, 5 \& 6).

\section{Structures and deformation related to the $S A B$ collision}

In Vedi area, $\mathrm{N} 130^{\circ} \mathrm{E}$ trending folds deform the Palaeozoic to Santonian formations of the SAB the ophiolites and the foreland basin (Fig. 5). Paleocene to Oligocene molasses covering the ophiolites are deformed by ramp anticlines (Fig. 6). As a result of the southwestward folding propagation, Eocene and Oligocene series are deposited with onlap relationships over the Palaeozoic-Mesozoic anticline cores (Fig. 6). The anticline cores are made of Palaeozoic formations from the SAB. For example, to the SE part of Vedi area the Oligocene formations unconformably cover the Permian.
The corresponding tectonic phase is due to the southwestward propagation of the collisional deformation. These types of structures, featured by folds and ramps are related to décollement levels within the Devonian series and the ophiolites (serpentinites) (Fig. 6).

In contrast, the Miocene volcanic rocks seal the structures related to this deformation phase (Unconformity U3), as they appear to be monoclinal (Fig. 5). As a result the folding event can be bracketed between the Oligocene and Miocene periods. More precision on the age of these Neogene series is needed to accurately constrain the age range of the NE-SW shortening event responsible to folding. The disconformity (U4) of the Plio-Quaternary volcanites on the Miocene volcanic and sedimentary rocks is well exposed in this area (Figs 5, $6 \& 8$ ).

The structural interpretation on Figure 6 takes into account the occurrence of reactivated normal faults in the Palaeozoic series and a crustal-scale active fault (the Garni Fault: a currently dextral strike-slip fault, Rebai et al. 1993; Philip et al. 2001) precisely located at the anticline axis of the main structure (Figs $5 \& 6$ ). This interpretation is in favour of inherited structures within the SAB basement which have been reactivated during the Cenozoic, and still currently active faults (Philip et al. 2001; Karakhanian et al. 2004; Avagyan et al. 2005).

In the north area of the Sevan Lake two main unconformities have been observed. The first one (U1) corresponds to the deposition of the Upper Cretaceous pelagic series over the ophiolitic sequence (Fig. 10). We dated these formations by nannofossil assemblages from Late-Coniacian to Late Campanian (Avazan and Artanish valleys, Table 1). The Maestrichtian would be present in some parts (Nalivkin 1976). The second one (U2), described above corresponds to the deposition of the late-Middle to Late Eocene series over deformed ophiolites and Late Cretaceous formations (Figs $9 \&$ 10). N $50-80^{\circ} \mathrm{E}$ trending folds deform the Campanian pelagic limestones and are related to a shortening event that occurred before the deposition of Nummulitic sediments. Moreover, N120- $130^{\circ}$ E trending reverse faults and thrusts cross-cut the Upper Eocene series all along the North Sevan Lake from Artanish to Zod (Figs 9, 10 \& 11). These structures also occur all along the suture zone from the Transcaucasus massif to the Karabakh (Fig. 2) and in front of the belt from Transcaucasus domain to the southeastward end of the Lesser Caucasus in Armenia and Nakhijevan.

\section{Timing of the collision stages}

According to the stratigraphical and structural data the collision between SAB and Eurasia started 
during the Paleocene as evidenced by the formations of a foreland basin in the southeastern part of the belt and by the folding and uplift of the Sevan-Akera suture zone. Following this uplift and erosion phase it is very probable that during Early Eocene the north flank of the suture zone and the Eurasian margin subsided, resulting in deposition of Lower Eocene detrital rocks and magmatism. Nevertheless uplift to the South, along the suture zone, and subsidence to the north along the southern Eurasian margin must have been coeval, resulting in a huge erosional surface on which late-Middle Eocene shallow marine sediments were deposited. Some normal faults in the Upper Eocene volcanites were reactivated as post Eocene thrust faults are present in the North Sevan Lake area (e.g. Fig. 10, cross-section B).

During the Paleocene to late-Middle Eocene in the southern (Armenian) part, a flexural molassic basin covered the obducted ophiolite and related structures, and was progressively deformed along thrusts and décollement faults developing a fold-and-thrust belt type until the Miocene (Fig. 6). Some of the normal faults within the SAB Palaeozoic formations and the basement have been reactivated as reverse faults (Fig. 6). We presume that these faults were normal faults responsible for titled blocks of the north SAB passive margin.

The Miocene epoch corresponds to a drastic transition in the deformation style of the belt. As clearly evidenced by the Vedi area cross-section, folding is stopped and a huge erosion surface marks the transition (Figs 2, 3, 5 \& 6). However, strain field evolved, and the shortening direction changed from NE-SW to NNW-SSE (Avagyan et al. 2005). This shift in strain direction produced reactivation of the main $\mathrm{N} 130^{\circ} \mathrm{E}$ trending previous structures as left-lateral strike-slip faults with a reverse component. Since then deformation has remained with similar features, which resulted in the opening of NW-SE elongated volcanic clusters in the main shortening direction, and in a general uplift of the area (Karakhanian et al. 2004; Avagyan et al. 2005, 2010).

\section{Geodynamic evolution and discussion}

According to the new results presented above and with the help of numerous previous data mainly acquired during the Soviet period we can propose a new geodynamic model of the Lesser Caucasus evolution since the Late Jurassic (Fig. 12).

\section{Middle Jurassic to Coniacian}

According to palaeomagnetic data (Bazhenov et al. 1996) the SAB was located $2000 \mathrm{~km}$ south of its present position during the Middle Jurassic. Moreover from Middle Jurassic to Late Coniacian, two main subduction zones are responsible for: (1) the huge magmatic activity on the Eurasian active margin (Somkheto-Karabakh Island arc); (2) the calcalkaline magmatism on top of the oceanic lithosphere which have been obducted since Late Coniacian; and (3) occurrence of Blueschist unit (94-90 Ma). From the overall geometry, we can suspect a subduction towards the NW beneath the Eurasian margin, but the preceding stages of intra-oceanic subduction may be featured by different orientations. Based on stretching lineations, mineral HP-LT mineral lineations and senses of shear in the Stepanavan Blueschist unit, Rolland et al. (2007) suggest an east-verging intra-oceanic subduction zone. However this direction could have been rotated during collision. Whatever in this hypothesis the ophiolites of the Lesser Caucasus belongs to a marginal basin opened in back-arc position within the Neotethys Ocean (lherzolite ophiolite type [LOT] ophiolites, low spreading rate, Galoyan 2008; Galoyan et al. 2009; Rolland et al. 2009). All these results and the geochemical characteristics of the oceanic basalts evidence a SSZ type for the intra-oceanic subduction zone (Rolland et al. 2009).

On the Eurasian margin we have observed a preConiacian erosional surface and disconformity of Coniacian and Santonian arc-type series characterized by a basal reddish conglomerate reworking the island arc series and their Upper Jurassic intrusions. Consequently during the Early Cretaceous an active erosion event took place, which resulted in the unroofing of plutons of the magmatic arc (Azerbaijan, mark E on Fig. 2). This erosion event is the result of significant uplift and denudation during the Early Cretaceous. The reasons for such a change in the Eurasian active margin strain field could be the subduction of the spreading ridge of the back-arc basin (see Fig. 12) or the entrance in the subduction zone of an oceanic plateau or an intra-oceanic ridge, which is suspected from the geochemical analysis of alkaline basalt on the ophiolites (Galoyan et al. 2007; Galoyan 2008; Rolland et al. 2009).

\section{Coniacian to Paleocene}

From the Coniacian to the Paleocene the intraoceanic subduction (SSZ) evolved to a continental subduction of the SAB beneath the intra-oceanic arc and the marginal basin (Fig. 12). This event is supported by HP-LT metamorphism at $94-90 \mathrm{Ma}$ of oceanic formations within an accretionary prism identified in the Stepanavan area (Fig. 2) (Rolland et al. 2007; Galoyan 2008). This step conducts around $5 \mathrm{Ma}$ later to the obduction of the ophiolites over the SAB. This is well evidenced by: 1) the ophiolites uplift evidenced by the Upper 


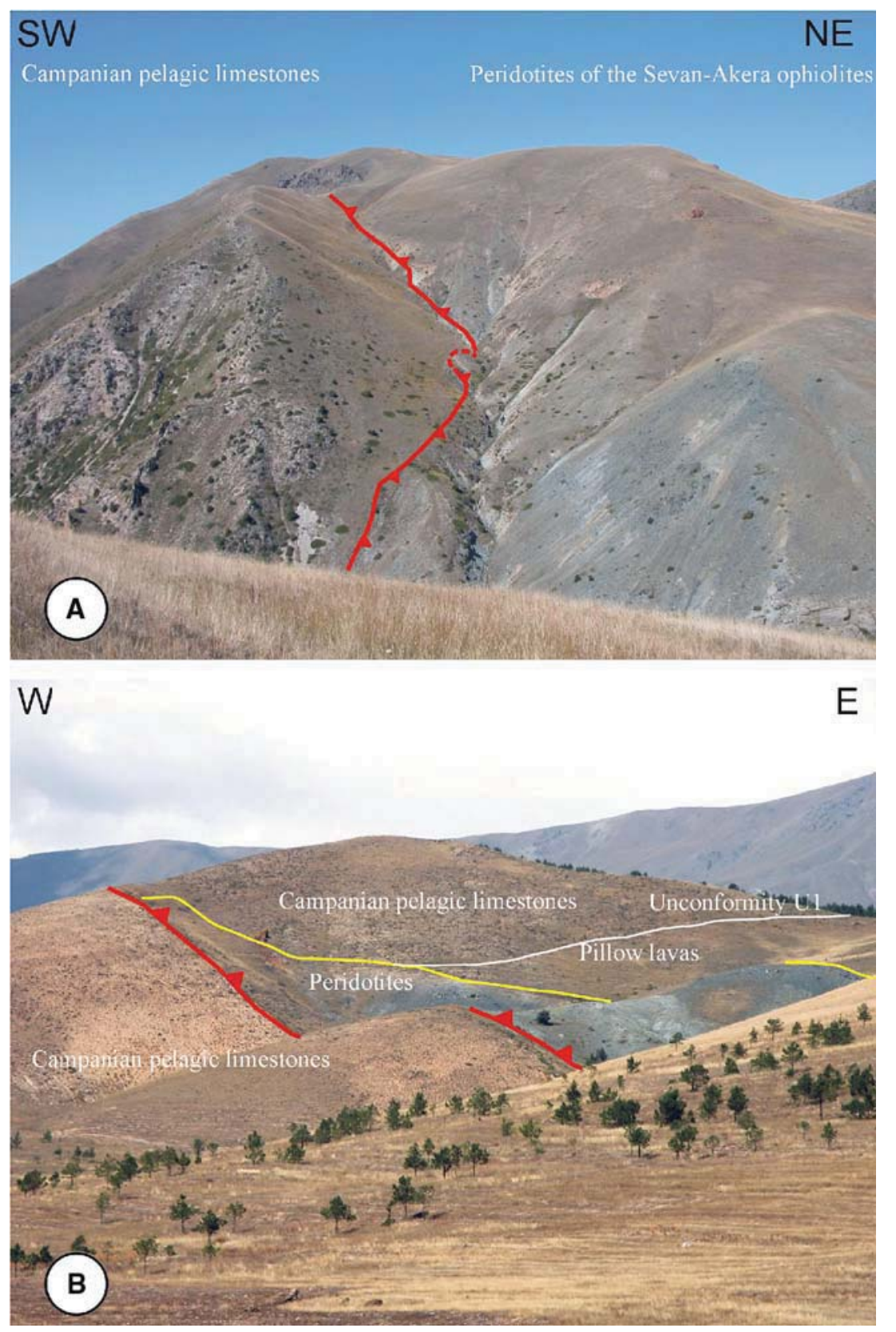

Fig. 11. Photographs of the post Eocene thrust faults in the northern Sevan Lake area; location of photo A shown on Figures 9 and 10, location of photo B shown on Figure 9.

Coniacian-Santonian reef limestone deposits on top of them in Vedi Area; 2) the coeval olistostrome formation beneath the ophiolitic thrust (Vedi and Sevan areas, Figs $8 \& 9$ ) and overlying Cenomanian-Turonian flysch of the SAB.
The Campanian-Maastrichtian formations are absent in the belt's frontal part, while they are present as pelagic sediments on the ophiolites of the Sevan-Akera zone. This lateral variation is ascribed to the southern frontal part's uplift 


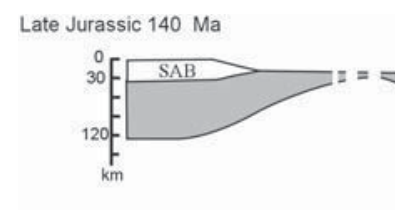

Coniacian-Santonian $88-83 \mathrm{Ma}$

OBDUCTION
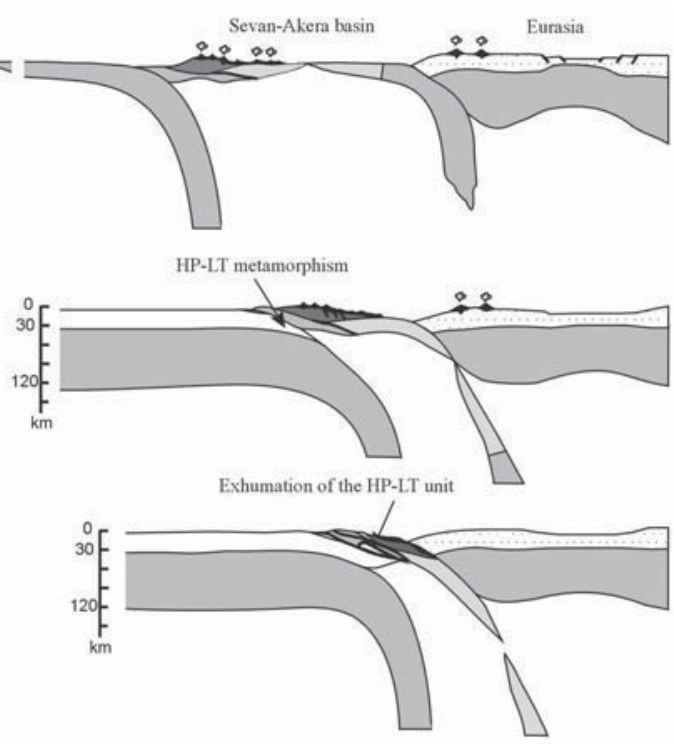

Paleocene $60 \mathrm{Ma}$

COLLISION

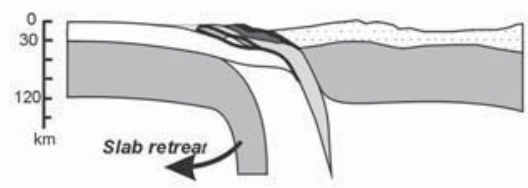

Early Eocene $50 \mathrm{Ma}$

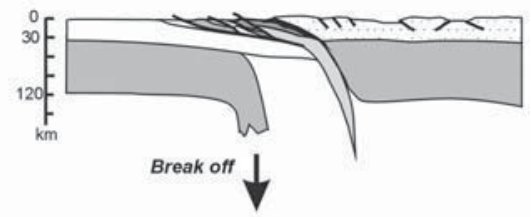

Late Eocene-Lower Miocene 40-20 Ma

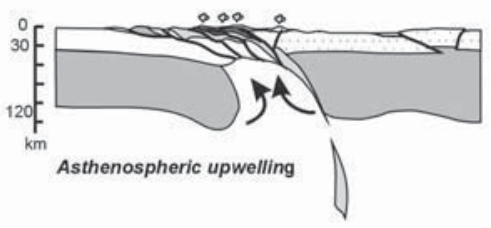

Late Miocene to Present

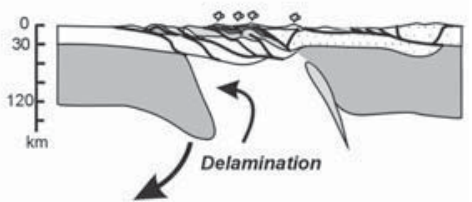

Fig. 12. Geodynamic model of the evolution of the Lesser Caucasus from Late Jurassic to present (see explanations in the text).

produced by the southward obduction thrust propagation and by a remnant oceanic crust covered by pelagic limestones to the north. The southern slope of this remnant oceanic crust (on the back of the obduction unit) was characterized by a northward dipping evidenced by north verging slumps within the Campanian pelagic deposits (Fig. 10 cross-section A). During the same time one notes 
the exhumation of the Blueschist unit along the previous intra-oceanic subduction zone (Rolland et al. 2007).

\section{Paleocene to Lower Miocene}

The occurrence of a foreland basin in front of the belt and the folding and erosion of the Sevan-Akera ophiolitic zone suggest the entrance of the SAB in the subduction zone below the Eurasian margin since the Paleocene, pulled by the dense eclogitized oceanic slab to which it is still attached.

Due to the low density of the SAB continental crust entering in the subduction contact under the Eurasian margin, the continental subduction produces: 1) the uplift, shortening, folding and erosion of the obducted unit on the SAB (The Sevan-Akera zone); 2) the thrusting and folding of the Eurasian margin formations; and 3) the southwestward transport of the erosional products to the flexural basin in the belt front.

The Lower to Middle Eocene magmatism on the Sevan-Akera suture zone (Lordkipanidze et al. 1988) could correspond to the first stage of a slab retreat triggered by the continental subduction and the break off of the continental lithospheric subducted mantle. Thermo-mechanical physical modelling has evidenced this mechanism (Boutelier et al. 2003, 2004). But more studies on the geochemical analysis of this magmatism must to be performed in order to test this model for the Lesser Caucasus region.

One prominent result of this study is that the time of oceanic closure, indicated by the late-Middle Eocene unconformity on the SAB, the suture zone and the Eurasian margin clearly pre-dates this epoch. Therefore, the huge magmatic activity occurring from Late Eocene to Miocene (Lordkipanidze et al. 1988; Karapetian et al. 2001) has to be explained in this collisional context. We suggest that the slab retreat and break off processes lead to an asthenospheric upwelling below the suture zone (Fig. 12). This mechanism could explain the location of magmatism all along the Lesser Caucasus. However, some geochemical studies would be necessary to test this assumption.

\section{Upper Miocene to present}

The continental subduction seems to be stopped but deformations still occur. The Arabian plate collision with the SAB to the South (in the Bitlis region, Oberhänsli et al. 2010 for a review), is responsible for the strain field's reorganisation (Philip et al. 2001; Avagyan et al. 2005 and references herein). This produces the reactivation of the thrusts as strike-slip faults and the opening of volcanic clusters (Avagyan et al. 2005). Due to the collision, one may explain the widespread magmatic activity by partial melting of overthickened continental crust (Mitchell \& Westaway 1999; Karapetian et al. 2001). Another possibility could be a slab break off process beneath Eastern Anatolia (Faccenna et al. 2006; Lei \& Zhao 2007). However, this second hypothesis does not seem appropriate to explain all the magmatic activity known in the Lesser Caucasus and Greater Caucasus regions, which are relatively far from Eastern Anatolia. Another solution could be that of asthenospheric upwelling (if this one has actually existed) producing significant weakening of the SAB continental lithospheric mantle, which begins its delamination. This could explain the magmatism and uplift of the Lesser Caucasus since Pliocene time. The question if whether asthenosphere upwelling is related or totally unrelated to the lithosphere-scale plate tectonic processes remains open.

\section{Conclusions}

The results coming out from studies undertaken in the Lesser Caucasus region allow to clarify the main questions on its tectonic and geodynamic evolutions.

(1) The Sevan-Akera suture zone represents the only suture of the belt. The other ophiolitic units (Vedi and Zangezur, Fig. 2) correspond to ophiolitic nappes due to the obduction of oceanic crust over the $\mathrm{SAB}$ or to tectonic slivers reworked by the Upper OligoceneLower Miocene thrusts and reverse faults. The collision stage has significantly deformed the initial obduction contact by folding and thrusting and then more recently by strikeslip faulting. Consequently all the identified ophiolitic units in the Lesser Caucasus have been remobilized and outcrop today thanks to these collisional structures, as in the cores of anticlines (Sevan Lake, Stepanavan areas) (Figs 2 \& 9) or in synclinal klippes (Vedi area) (Fig. 6) or as slivers along thrust faults (Zangezur and Amassia areas) (Fig. 2). In our interpretation of the structure of the Lesser Caucasus the ophiolites are continuous from Central to North Armenia, deep below the Sevan Lake (Fig. 3). The consequence of this structure is that the SAB is underthrusted below this huge ophiolite sliver, and may continue also below the Sevan Lake. This point is important in terms of natural resources because of the hydrocarbon potential of source rocks in the SAB Palaeozoic section. Indeed these source rocks could be capped by the allochthonous ophiolites, which could 
represent an overscreen under the Sevan Lake and the neighbouring regions.

(2) The onset of collision or the continental subduction of the SAB below the Eurasian margin is dated as Paleocene. This process occurred around $20 \mathrm{Ma}$ later than the obduction (Late Coniacian-Santonian, 88-83 Ma) of the marginal basin over the SAB. It led to the uplift of the Sevan-Akera suture zone, its folding, erosion and to the transfer of detrital materials in a flexural basin in front of the belt, above the obduction structures. From late-Middle Eocene to Miocene all the belt is deformed by thrusts and reverse faults in the internal part (Transcaucaus to Karabakh, Fig. 2) and by $\mathrm{N} 130^{\circ} \mathrm{E}$ trending fold and thrust belt at the chain front. One can note an evolution from thin-skin to thick-skin tectonics in front mainly due to the reactivation of the previous normal faults in the $\mathrm{SAB}$
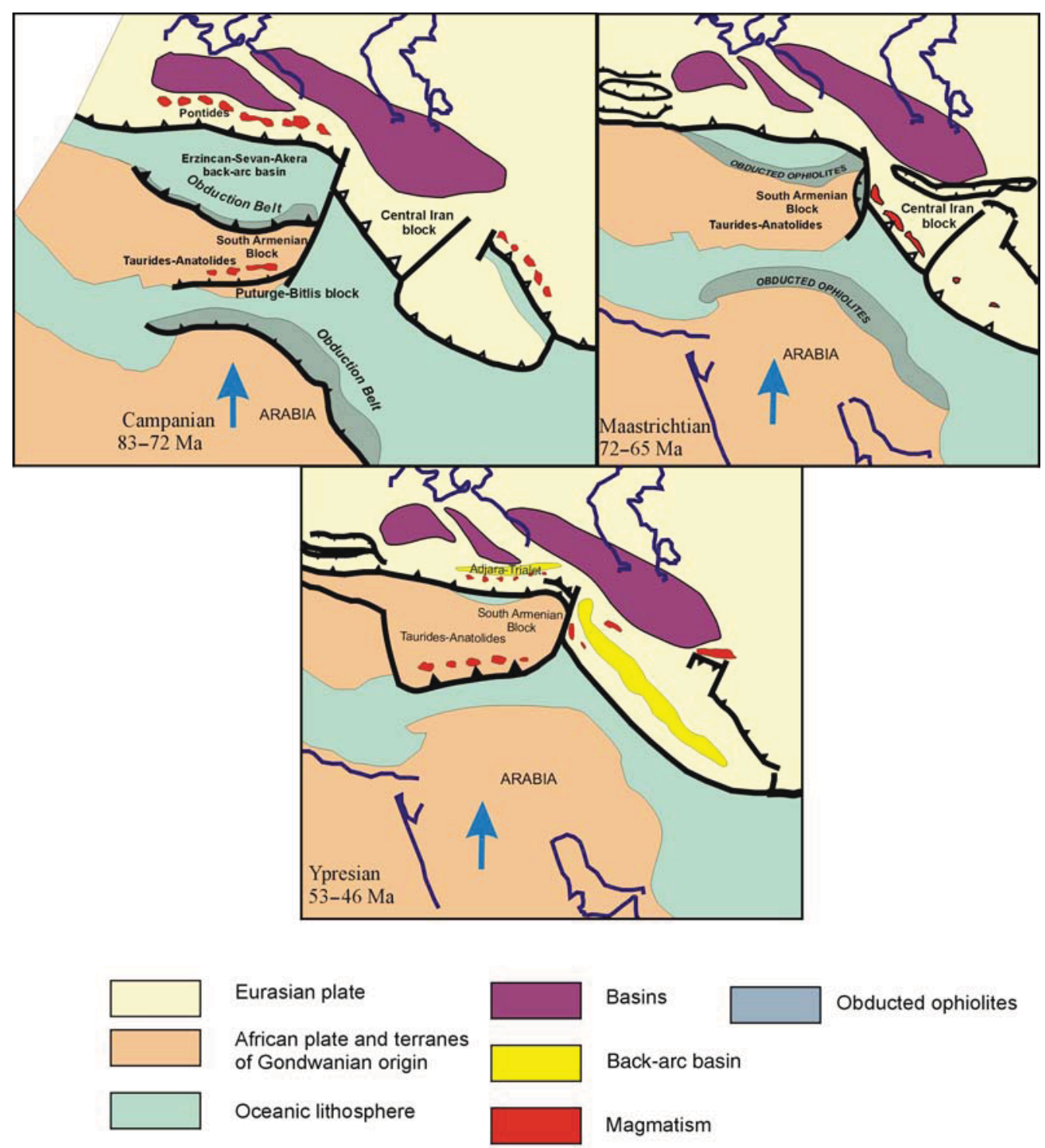

Fig. 13. Campanian, Maestrichrian and Ypresian palaeotectonic maps of the Lesser Caucasus region and its neighbouring areas (modified from Barrier \& Vrielynck 2008). 
basement at depth (Vedi and Southeast Armenia area, Figs $2 \& 3$ ).

(3) The widespread Eocene to recent magmatic activity is the result of various, still enigmatic processes. The Eocene magmatic activity occurred after the onset of the collision. Consequently it cannot be directly related to the oceanic subduction processes except for the Adjara-Trialet massif in Georgia considered as a back-arc basin due to a oceanic subduction of a small remnant oceanic lithosphere NW of the Sevan-Akera Suture zone (Adamia et al. 1981; Barrier \& Vrielynck 2008). We suggest the possibility of a slab retreat and a break off allowing the rising of the asthenospheric mantle, which could have heated the overthickened continental crust (Fig. 12). The Miocene to recent magmatic activity seems to be related to 1) a possible asthenosphere upwelling beneath the suture zone after the break off and, 2) strain field reorganization at these times due to the Arabian plate collision with the SAB producing opening of volcanic clusters along main inherited faults (Karakhanian et al. 2004; Avagyan et al. 2005, 2010).

The Lesser Caucasus is a key area to understand lateral connections with the Taurides-Anatolides to the west and the Iranian regions to the East. Indeed, as demonstrated by Stöcklin (1974) and developed by Zanchi et al. (2009) the Eo-Cimmerian orogen is discontinuously exposed along the northern side of the Alborz Mountains of north Iran below the siliciclastic deposits of the Shemshak Group (Late Triassic-Jurassic). However, a thick comparable Shemshak-type basin is unknown in the Lesser Caucasus. In this belt the contact between the Upper Triassic detrital series and the Lower Triassic carbonates formations is not well exposed. A complete sequence has been described in the Nakhijevan part of the Lesser Caucasus (Barzenov et al. 1995). Nevertheless, no evidence of Eo-Cimmerian orogeny has been found in the Lesser Caucasus. These features conduct to expect in the study area a major stratigraphic and structural limit. Consequently, the oriental border of the continental blocks of Taurides-Anatolides and South Armenian Block of Gondwanian origin need to be clarified. This block collided with Eurasia during Paleocene Eocene times. According to the MEBE palaeotectonic map (Fig. 13) (Barrier \& Vrielynck 2008) the passage between Lesser Caucasus and NW Iran (NW Alborz and Tabriz-Saveh) would be then a syntax similar to those delimiting India colliding with Asia, but it remains to be demonstrated. One way to explain the problems is the existence of NE-SW orientated Araks strike-slip fault, suggested as an oriental border of Lesser Caucasus (Fig. 1). But if this fault has a recent expression, it is not sure that it was present at the beginning of the collision between the South Armenian Block and Eurasia.

New interpretations allow some points to be studied in more detail, particularly the origin of the widespread collisional magmatism and the connections with the Iranian belt, which remain to this day a subject of debate.

This work was financed by INTAS and since 2003 by the Middle East Basins Evolution (MEBE) programme. Many thanks to the MEBE programme coordinators E. Barrier and M. Gaetani, for their support and encouragement. Fieldworks were greatly facilitated by the support of the Institute of Geological Sciences (Armenia), the Geological Institute of Azerbaijan and the Institutes of Geophysics and Geology (Georgia). We also thank the support of the French Embassy at Yerevan (Armenia) for the MAE PhD grant of G. Galoyan. The reviews by A. Tremblay and A. Zanchi are highly acknowledged.

\section{References}

Abesadze, M., Adamia, Sh., Chkhotua, T., TsimaKURIDZE, G. \& Shavishvili, I. 2002. Structure and development of the Loki salient of the Transcaucasus. Proceedings, Geological Institute Academy of Sciences, Georgia, new series, 1127, 135-145 (in Russian).

Abovyan, S. B. 1961. Geology and the Minerals (Ores) of the North-Eastern Coast of Sevan Lake. Izdatelstvo NAS Arm. SSR, Yerevan (in Russian).

Adamia, S. 1968. Pre-Jurassic formations of the Caucasus. Proceedings of the Geological Institute of Academy of Sciences of Georgia, new series, 16, 1-295 (in Russian).

Adamia, S. 1984. Prealpine basement of the Caucasus composition, structure, and formation. In: ОткнмеZURI, Z. V. (ed.) Tectonika I metallogenia Kavkaza. Metsniereba, Tbilisi, 86, 3-104.

AdAMia, S., LoRdKipanidZe, M. \& ZaKariadZe, G. 1977. Evolution of an active continental margin as exemplified by the Alpine history of the Caucasus. Tectonophysics, 40, 183-199.

Adamia, S. A., Chkhotia, T., Kekelia, M. \& LordkipaNIDZE, M. 1981. Tectonics of Caucasus and adjoining regions: implications for the evolution of the Tethys ocean. Journal of Structural Geology, 4, 437-447.

Adamia, S., Kekelia, M. \& Tsimakuridze, G. 1983. Pre-variscan and variscan granitoids of the Caucasus. IGCP Newsletter, 5, 5-10.

Adamia, S., Belov, A., Kekelia, M. \& Shavishvili, I. 1987. Paleozoic tectonic development of the Caucasus and Turkey (Geotraverse C). In: Flugel, H. W., SASSI, F. P. \& Grecula, P. (eds) Pre-Variscan and Variscan Events in the Alpine-Mediterranean Mountain Belts. Mineralia Slovaca, Alfa Bratislava, 23-50.

Aghamalyan, V. A. 1978. The old metamorphic complexes of the territory of Armenian SSR and their tectonic disposition. Proceedings of Reports of the 
Second Regional Petrographic Symposium on Caucasus, Crimea and Carpathians. Tbilisi, 109-115 (in Russian).

Aghamalyan, V. A. 1981. Blueschist formation. In: Magmatic and Metamorphic Formations of Armenian SSR. House of Academy of Sciences of Armenian SSR, Yerevan, 121-122 (in Russian).

Aghamalyan, V. A. 1996. Formation and the evolution of the earth's crust of the region of the articulation of the passive and active margins of Tethys based on the example to Armenia. Regularities of the Evolution of the Earth's Crust. Report 2, Institute of Geological Sciences of the Academy of Sciences of Armenia (in Russian).

Aghamalyan, V. A. 1998. The Basement Crystalline of Armenia. $\mathrm{PhD}$ thesis, Institute of Geological Sciences, National Academy of Sciences of Armenia. Yerevan (in Russian).

Aghamalyan, V. A. 2004. The Lesser Caucasus earth crust formation and evolution in the collision zone of Paleo-Tethys. 5th International Symposium on Eastern Mediterranean Geology. Thessaloniki, Greece, 14-20 April 2004, 17-20.

Aslanyan, A. T. \& Satian, M. A. 1977. On the geological features of Transcaucasian ophiolitic zones. Izvestia Academy of Sciences Armenian SSR, Nauki o Zemle 4-5, 13-26 (in Russian).

Aslanyan, A. T. \& Satian, M. A. 1982. Middle Cretaceous ophiolite zones of Transcaucasus and tectonic reconstructions. Ofioliti, 7, 131 (abstract).

Avagyan, A., Sosson, M. ET AL. 2005. Neogene to Quaternary stress field evolution in Lesser Caucasus and adjacent regions using fault kinematics analysis and volcanic cluster data. Geodinamica Acta, 18, 401-416.

Avagyan, A., Sosson, M. ET AL. 2010. Recent tectonic stress evolution in the Lesser Caucasus and adjacent regions. In: Sosson, M., KAYMAKCI, N., Stephenson, R. A., Bergerat, F. \& Starostenko, V. (eds) Sedimentary Basin Tectonics from the Black Sea and Caucasus to the Arabian Platform. Geological Society, London, Special Publications, 340, 393-408.

Barrier, E. \& Vrielynck, B. 2008. Palaeotectonic map of the Middle East, Atlas of 14 maps, Tectonosedimentary-Palinspastic maps from Late Norian to Pliocene. Commission for the Geologic Map of the World (CCMW, CCGM), Paris, France.

Bazhenov, M., Burtman, V. S. \& Levashova, N. M. 1996. Lower and Middle Jurassic paleomagnetic results from the south Lesser Caucasus and the evolution of the Mesozoic Tethys ocean. Earth and Planetary Science Letters, 141, 79-89.

Babazadeh, V. M., Ramazanov, V. G., Mammadov, Z. I., Ismailova, A. M. \& Abdullayeva, Sh. F. 2007. Geological-geophysical and geochemical fundamentals of the model of ore-magmatic systems of porphyry-copper deposits of the Kedabek ore district. Proceedings of Scientific Session Dedicated to 100th Anniversary of Academician M. A. Kashkai. Baku, 58-84.

Belov, A. A. \& Sokolov, S. D. 1973. Relicts of Mesozoic oceanic crust among the crystalline complexes of the Miskhana massif of Armenia. Sovetskaya Geologia, 8, 26-41 (in Russian).
Belov, A. A., Bragin, N. Yu., Vishnevskaya, V. S., Satian, M. A. \& Sokolov, S. D. 1991. New data about the age of the ophiolites of Vedi (Armenia). Reports of the USSR Academy of Science, 321, 784-787 (in Russian).

Boutelier, D., Chemenda, A. \& Burg, J.-P. 2003. Subduction versus accretion of intra-oceanic volcanic arcs: insight from thermo-mechanical analogue experiments. Earth and Planetary Science Letters, 212, $31-45$.

Boutelier, D., Chemenda, A. \& Jorand, C. 2004. Continental subduction and exhumation of high-pressure rocks: insights from thermo-mechanical laboratory modelling. Earth and Planetary Science Letters, 222, 209-216.

Danelian, T., Galoyan, G., Rolland, Y. \& Sosson, M. 2007. Palaeontological (Radiolarian) Late Jurassic age constraint for the Stepanavan ophiolite (Lesser Caucasus, Armenia). In: Proceedings of the 11th International Congress, Athens, May 2007. Bulletin of the Geological Society of Greece, 40, 31-38.

Danelian, T., Asatryan, G., Sosson, M., Person, A., Sahakyan, L. \& Galoyan, G. 2008. Discovery of two distinct Middle Jurassic Radiolarian assemblages in the sedimentary cover of the Vedi ophiolite (Lesser Caucasus, Armenia). Comptes Rendus, serie Palevol, 7, 324-334.

Danelian, T., Asatryan, G., Sahakyan, L., Galoyan, G. H., Sosson, M. \& Avagyan, A. 2010. New and revised Radiolarian biochronology for the sedimentary cover of ophiolites in the Lesser Caucasus (Armenia). In: Sosson, M., Kaymakci, N., Stephenson, R. A., Bergerat, F. \& Starostenko, V. (eds) Sedimentary Basin Tectonics from the Black Sea and Caucasus to the Arabian Platform. Geological Society, London, Special Publications, 340, 383-391.

Dercourt, J., Zonenschain, L. P. ET AL. 1986. Geological evolution of the Tethys belt from the Atlantic to the Pamirs since the Lias. Tectonophysics, 123, $241-315$.

Eghoyan, V. L. 1955. The Upper-Cretaceous Deposits of the South-Western Part of Armenian SSR. Izdatelstvo NAS Arm. SSR, Yerevan (in Russian).

Faccenna, C., Bellier, O., Martinod, J., Piromallo, C. \& Regard, V. 2006. Slab detachment beneath eastern Anatolia: a possible cause for the formation of the North Anatolian fault. Earth and Planetary Science Letters, 242, 85-97.

Galoyan, G. 2008. Etude Pétrologiques, Géochimiques et Géochronologiques des Ophiolites du Petit Caucase (Arménie). PhD thesis, University of Nice-Sophia Antipolis.

Galoyan, G., Rolland, Y., Sosson, M., Corsini, M. \& MelKonian, R. 2007. Evidence for superposed MORB, oceanic plateau and volcanic arc series in the Lesser Caucasus (Stepanavan, Armenia). Comptes Rendus Geosciences, 339, 482-492.

Galoyan, G., Rolland, Y., Sosson, M., Corsini, M., Billo, S., Verati, C. \& Melkonian, R. 2009. Geology, geochemistry and ${ }^{40} \mathrm{Ar} /{ }^{39} \mathrm{Ar}$ dating of Sevan ophiolites (Lesser Caucasus, Armenia): Evidence for Jurassic Back-arc opening and hot spot event between the South Armenian Block and Eurasia. Journal of Asian Earth Sciences, 34, 135-153. 
Gevorkyan, R. G. \& Gevorkyan, M. R. 2003. Ophiolitic Paleooceanic Crust of Armenia (South Caucasus). Yerevan, GEOID (in Russian).

Grigorian, A. 1990. The Conodonts of the PermianTriassic limit in Armenia. $\mathrm{PhD}$ thesis Abstract, University of Moscow (in Russian).

Golonka, J. 2004. Plate tectonic evolution of the southern margin of Eurasia in the Mesozoic and Cenozoic. Tectonophysics, 381, 235-273.

Haковyan, V. T. 1978. Biostratigraphy of the Upper Cretaceous Deposits of Armenian SSR. Izdatelstvo NAS Arm. SSR, Yerevan (in Russian).

Karakhanian, A., Jrbashyan, R. ET aL. 2004. Active volcanoes and volcanic hazard in the Armenian Highland and adjacent areas. Izvestia NAS of RA, LVII, 3-24.

Karapetian, S. G., Jrbashian, R. T. \& Mnatsakanian, A. KH. 2001. Late collision rhyolitic volcanism in the north-eastern part of the Armenian Highland. Journal of Volcanology and Geothermal Research, 112, 189-220.

KARYAKIN, Y. V. 1989. Geodynamics of the Formation of the Volcanic Complexes of the Lesser Caucasus. Moscow 'Nauka' (in Russian).

Kazakhashvili, T. G. 1950. Petrographic Study of the Loki-Jandari Crystalline Massif Tbilisi, 1-90 (in Russian).

Kekelia, M. \& Khutsishvili, O. 1980. Petrological peculiarities of the rocks of gneiss-migmatite complex of the Khrami salient. Proceedings of Geological Society of Georgia, 9, 109-116 (in Russian).

Kekelia, S., Kekelia, M., Otkhmezuri, Z. \& Moon, CH. 2004. Metallogeny of active paleomargins of continents (on example of Alpine metallic deposits of Caucasus and Pontides). Proceedings of the Geological Institute of Academy of Sciences of Georgia, new series, 119, 706-727.

KnIPPER, A. L. 1975. The oceanic crust in the structure of the Alpine Folded Belt (South Europe, western part of Asia and Cuba). Transactions, 267, Moscow 'Nauka' (in Russian).

KNIPPeR, A. L. \& SoKolov, S. D. 1976. Vedi ophiolites (Armenia) autochton or allochton? Geotektonica, 4 54-66 (in Russian).

KNIPPer, A. L. \& KhaIN, E. V. 1980. Structural position of ophiolites of the Caucasus. Ofioliti, Special Issue, 2, 297-314.

KNipper, A. L., Ricou, L. E. \& Dercourt, J. 1986. Ophiolites as indicators of the geodynamic evolution of the Tethyan ocean. Tectonophysics, $\mathbf{1 2 3}$, 213-240.

LEI, J. \& ZHAO, D. 2007. Teleseismic evidence for a breakoff subducting slab under Eastern Turkey. Earth and Planetary Science Letters, 257, 14-28.

Lordkipanidze, M., Meliksetian, B. \& Djerbashian, R. 1988. Mesozoic-Cenozoic magmatic evolution of the Pontian-Crimean-Caucasian region. Mémoire de la Société Géologique de France, 154, 103-124.

MaghaKyan, R., ZaKariadze, G., Dmitriev, L. Kolesov, G. \& Korovina, M. 1985. Geochemistry of the Jurassic-Lower cretaceous volcanic assemblage of northern Armenia. Volcanology and Seismology, $\mathbf{3}$ 39-53 (in Russian).
Melikyan, L. S. 2004. Some geological and structural features of inner structure of the Amassiya-Sevan ophiolitic zone (Republic of Armenia). Izvestia NAS of Armenia, Nauki o Zemle, 3, 32-38 (in Russian).

Melkonian, R. L. 1976. Petrology, mineralogy and geochemistry of the complexes of Alaverdi ore region. In: Petrology and Geochemistry of the Intrusive Complexes of Some Ore Regions. Ana of Armc SSR, Armenian SSR (in Russian).

Melkonyan, R. L. \& Akopyan, M. S. 2006. Some aspects of the interrelations between magmatism and ore formation: evidence from oxygen isotope data on ore-magmatic systems, Armenia. Petrology, 14, 413-420.

Milanovski, E. E. 1968. Neotectonics of the Caucasus. Nedra, Moscow (in Russian).

Mitchell, J. \& Westaway, R. 1999. Chronology of Neogene and Quaternary uplift and magmatism in the Caucasus; constraints from $\mathrm{K}-\mathrm{Ar}$ dating of volcanism in Armenia. Tectonophysics, 304, 157-186.

Monin, A. S. \& Zonenshain, L. P. (eds) 1987. History of the Ocean Tethys. Moscow Institute of Oceanology (in Russian).

Nalivkin, P. V. (ed.) 1976. Geological Map of Caucasus at 1/500 000 scale. Ministry of Geology, USSR, Cief.

Nikishin, A. M., Cloething, S., Brunet, M.-F., StePhenson, R. A., Bolotov, S. N. \& Ershov, A. V. 1998. Scythian Platform, Caucasus and Black Sea Region: Mesozoic-Cenozoic tectonic history and dynamics. In: Crasouin-Soleau, S. \& Barrier, E. (eds) Peri-Tethys Memoir 3: Stratigraphy and Evolution of Peri-Tethyan Platforms. Mémoire du Muséum d'Histoire Naturelle, Paris, 177, 163-176.

Oberhänsli, R., CAndan, O., Bousquet, R., Rimmele, G., OKaY, A. \& GofF, J. 2010. Alpine high pressure evolution of the eastern Bitlis complex, SE Turkey, GSL. In: Sosson, M., Kaymakci, N., Stephenson, R. A., Bergerat, F. \& Starostenko, V. (eds) Sedimentary Basin Tectonics from the Black Sea and Caucasus to the Arabian Platform. Geological Society, London, Special Publications, 340, 461-483. Paffenholtz, K. N. 1959. Geological History of the Caucasus. Izdatelstvo NAS Arm. SSR (in Russian).

Philip, H., Avagyan, A., Karakhanian, A., Ritz, J.-F. \& REBAÏ, S. 2001. Estimating slip rates and recurrence intervals for strong earthquakes along an intracontinental fault: example of the Pambak-Sevan-Sunik fault (Armenia). Tectonophysics, 343, 205-232.

Rebaï, S., Philip, H., Dorbath, L., Borissoff, B., Haessler, H. \& Cisternas, A. 1993. Active tectonics in the Lesser Caucasus: coexistence of compressive and extensional structures. Tectonics, 12, 1089-1114.

Rengarten, V. P. 1959. Stratigraphy of the Cretaceous Deposits of the Lesser Caucasus. Regional Stratigraphy of USSR. Izdatelstvo of AS of USSR, Moscow (in Russian).

Ricou, L. E. 1994. Tethys reconstructed: plates, continental fragments and their boundaries since $260 \mathrm{Ma}$ from Central America to South-eastern Asia. Geodinamica Acta, 7, 169-218.

Ricou, L. E., Dercourt, J., Geyssant, J., GrandJaCQuet, C., Lepvrier, C. \& BiJu-Duval, B. 1986. Geological constraints on the Alpine evolution of the Mediterranean Tethys. Tectonophysics, 123, 83-122. 
Robertson, A. H. F. 2002. Overview of genesis and emplacement of Mesozoic ophiolites in the Eastern Mediterranean Tethyan region. Lithos, 65, 1-67.

Rolland, Y., Galoyan, G., Sosson, M., Melkonyan, R. \& Avagyan, A. 2010. The Armenian Ophiolite: insights for Jurassic back-arc formation, Lower Cretaceous hot spot magmatism, and Upper Cretaceous obduction over the South Armenian Block. In: Sosson, M., Kaymakci, N., Stephenson, R. A., Bergerat, F. \& Starostenko, V. (eds) Sedimentary Basin Tectonics from the Black Sea and Caucasus to the Arabian Platform. Geological Society, London, Special Publications, 340, 353-382.

Rolland, Y., Billo, S., Corsini, M., Sosson, M. \& Galoyan, G. 2007. Blueschists of the AmassiaStepanavan Suture Zone (Armenia): linking Tethys subduction history from E-Turkey to W-Iran. International Journal of Earth Sciences, doi: 10.1007/ s00531-007-0286-8.

Rolland, Y., Galoyan, G., Bosch, D., Sosson, M., CORSINI, M., Fornari, M. \& VÉrati, C. 2009. Jurassic Back-arc and hot-spot related series in the Armenian ophiolites - implications for the obduction process. Lithos, 112, 163-187.

Satian, M. A. 1979. The Late Cretaceous Lithogenesis of the Ophiolitic Zones of Armenian SSR (Lesser Caucasus). Izdatelstvo NAS Arm. SSR (in Russian).

Satian, M. A. 2005. Mesozoic ophiolite basins of the Transcaucasian geotraverse. Izvestia NAS of Armenia, 1, 3-8 (in Russian).

Sengör, A. M. C. \& Yilmaz, Y. 1981. Tethyan evolution of Turkey: a plate tectonic approach. Tectonophysics, 75, $181-241$.

Shengelia, D. M., Vashakidze, V. T. \& Poporadze, H. G. 1989. The new data regarded metamorphics of Lokhi crystalline salient of the Transcaucasian median massif. Dokladi Akademii Nauk SSSR, 30, 694-698 (in Russian).

SoKolov, S. D. 1977. The Olistostromes and Ophiolitic Nappes of the Lesser Caucasus. Izdatelstvo 'Nauka', Moscow (in Russian).
Stampfli, G. M., Mosar, J., Faver, P., Pillevuit, A. \& VAnNaY, C. J. 2001. Permo-Mesozoic evolution of the western Tethyan realm: the Neotethys/EastMediterranean connection. Peri-Tethys Memoir 6: Periththyan Rift/Wrench Basins and Passive Margins. International Geological Correlation Program, 369, 51-108.

StöCKLIN, J. 1974. Possible ancient continental margins in Iran. In: BuRK, C. A. \& DraKe, C. L. (eds) The Geology of Continental Margins. Springer, New York, 873-887.

Tsameryan, O. P., Zakariadze, G. S., Sobolev, A. V. \& Kononkova, N. N. 1988. Classifying of ophiolite volcanic series of Minor Caucasus based on the composition of rocks and melts. Geochemistry, 8 , 1140-1158 (in Russian).

Yilmaz, A., Adamia, S., Chabukiani, A., Chkhotua, T., Erdogan, K., Tuzcu, S. \& Karabiyikoglu, M. 2000. Structural correlation of the southern Transcaucasus (Georgia)-eastern Pontides (Turkey). In: Bozcuri, E., Winchester, J. A. \& Piper, J. D. A. (eds) Tectonics and Magmatism in Turkey and the Surrounding Area. Geological Society, London, Special Publications, 173, 171-182.

Zakariadze, G. S., Knipper, A. V., Sobolev, O. P., Tsamerian, Q. V., Dmitiev, L. V., VishnevsKaya, V. S. \& Kolesov, G. M. 1983. The ophiolite volcanic series of the Lesser Caucasus. Ofioliti, 8, 439-466.

Zakariadze, G. S., Karpenko, S. F., Bazylev, B. A., Adamia, Sh. A. \& Oberhaensli, R. E. 1998. Petrology, geochemistry, and $\mathrm{Sm}-\mathrm{Nd}$ age of the pre-late Variscan paleooceanic complex of the Dzirula salient, Transcaucasian massif. Petrology, 6, 388-408 (translated from Petrologiya, 6, 422-444).

ZANChI, A., Zanchetta, S. ET AL. 2009. The Eo-Cimmerian (Late? Triassic) orogeny in north Iran. In: Brunet, M.-F., WilmSEN, M. \& GRANATH, J. W. (eds) South Caspian to Central Iran Basins. Geological Society, London, Special Publications, 312, $31-55$. 